\title{
SITE-PLANNING PRINCIPLES AND CONCEPTS OF DIRECTIONALITY AMONG THE ANCIENT MAYA
}

\author{
Wendy Ashmore
}

\begin{abstract}
Many societies use architecture for symbolic expression, and often buildings or other constructions constitute maps of a culture's worldview. Archaeological identification of such ideational expressions is receiving renewed attention, in the Maya area as in many other regions. Excavations in 1988-1989 in Groups $8 L-10$ through $8 L$ 12, Copán, Honduras, were designed to examine a particular model of ancient Maya site planning and spatial organization, in which the principles of architectural arrangement and their directional associations derive from Maya cosmology. This paper describes the model and its archaeological evaluation at Copán and discusses interpretive implications of the specific results obtained, in the context of other ongoing studies in epigraphy, iconography, and archaeology.
\end{abstract}

Muchas de las sociedades mundiales expresan sus ideologías a través de la arquitectura, y frecuentemente los edificios $u$ otras construcciones sirven como mapas de la cosmologia de una sociedad. La identificación de tales usos simbólicos adquiere más relevancia arqueológica en años recientes, en el área maya como en otros lugares. Excavaciones en 1988-1989 en los Conjuntos 8L-10 a 8L-12, Copán. Honduras, se orientaron a probar un modelo antiguo de planificación arquitectónica maya, un modelo en el cual el origen del arreglo y de la orientación de la arquitectura se deriva de la cosmologia maya. Específicamente el modelo afirma que se establecieron los Conjuntos $8 \mathrm{~L}-10$ a $8 \mathrm{~L}-12$ intencionalmente como ápice norteño de un patrón triangular microcósmico y que esa posición se asoció con el cielo en donde vivieron los antepasados reales. Por las excavaciones de $1988-1989$ se encontraron más de 100 rasgos de escultura arquitectónica y una serie de depósitos ceremoniales (escondites y tumbas) entre los cuales se han identificado evidencias de conmemoración del Rey 18 Conejo, ya muerto, y de su dinastía. Este artículo describe el modelo y las pruebas arqueológicas, e indica las implicaciones interpretativas de los resultados, por el contexto más ámplio de estudios corrientes en la epigrafía, la iconografía, y la arqueología.

Symbolic manipulation of space is a common theme in architecture the world over (e.g., Blier 1987; Fernandez 1977; Lawrence and Low 1990; Tuan 1977). Even the most mundane components of the built environment have often been shown to convey rich symbolic messages. Diverse analysts have demonstrated that, in many cultures, house layouts define separable locations for activities associated with different genders and with variable levels of ritual purity, domestic intimacy, social standing, and the like. In this manner, house interiors often constitute microcosms, or worldview maps, providing ever-present spatial charts of the emic structure of social and ideological relationships (e.g., Bourdieu 1973, 1977; Donley 1982; Douglas 1972; Hodder 1984, 1987, 1990; Nabakov and Easton 1989).

Comparable analyses of symbolically structured space have focused at both smaller and larger scales, from burials and other relatively compact ritual deposits, to entire communities and wider landscapes (e.g., Benson 1981; Coe 1988; Fritz 1978; Hodder 1984, 1990; Taçon 1991; Taylor 1987; Tuan 1977). Within this overall range of foci, public buildings and building complexes (including elite, chiefly, or royal domiciles) have likewise been identified as microcosms (e.g., Leach 1983), and as among the least subtle in their symbolic portrayal of cosmic and social structuring. Such civic architecture frequently focuses on placing political and/or religious leaders in locations which themselves convey authority; lest any miss the point of such placement, the locations are often marked with multiple and redundant messages signaling authority, via symbols appropriate to the

\footnotetext{
Wendy Ashmore, Department of Anthropology, Douglass Campus, P.O. Box 270, Rutgers-The State University of New Jersey, New Brunswick NJ 08903-0270
}

Latin American Antiquity, 2(3), 1991, pp. 199-226.

Copyright (C) 1991 by the Society for American Archaeology 
particular culture (e.g., Fritz 1978, 1986; Kuper 1972; Niles 1987; Steinhardt 1986; Tuan 1977). Forms of marking include imposing mass, distinct architectural forms (e.g., the dome shape of many state and federal capitals in the United States), and representational adornment alluding to authority (e.g., inscriptions, sculptures, mural painting). What is important here is that the marking also involves location, often but not always prominently central, within the civic center and the community as a whole.

For the ancient Maya, studies of spatial symbolism in architectural arrangement are receiving renewed attention. The oldest and best-known analyses have been archaeoastronomical ones (e.g., Aveni 1980; Aveni and Hartung 1986; Ruppert 1977), and some analysts have examined the simultaneous architectural expression of both astronomical and political symbolism (Aveni and Hartung 1978; Coggins 1980; Fialko 1988; Fox 1987, 1991; Laporte and Fialko 1990; Miller 1985; Schele 1977; Tate 1985). Various recent studies have treated an expanded range of symbolically structured spatial arrangements (e.g., Ashmore 1980; Clancy 1988; Coe 1988; Freidel and Schele 1988b:556; Hammond 1987; Justeson et al. 1988:106-107; Wren 1989). And several (e.g., Ashmore 1986; Ashmore, comp. 1989; Coe 1965; Coggins 1980; de Montmollin 1988; Fox 1987, 1991; Freidel 1986; Schele 1977; Tate 1985) have suggested that, like counterparts in many other cultures, Maya buildings and civic centers were laid out as microcosms, arranging architecture so as to symbolically equate the architectural center of civic power with the center of the universe.

This paper outlines some principles believed to have structured ancient Maya symbolic space, presents a hypothesis about the specific symbolism involved, and summarizes initial evaluations of the hypothesis conducted in a pair of building compounds at Copán, Honduras (Ashmore 1989a, 1989b; Ashmore, comp. 1988, 1989). The two compounds likely served as elite residences, but as will be argued below, they probably had wider civic roles as well. The research is still exploratory, and the interpretations offered should be viewed as propositions, rather than confirmed conclusions. Still, the implications of findings to date reinforce a growing belief that this kind of research holds much promise for expanding archaeological study of ancient belief systems, Maya and other.

\section{THE MODEL: A SET OF PRINCIPLES AND THEIR INFERRED MEANING}

A prime focus of this paper is ancient Maya use of cardinal directions as symbolically charged positions in architectural arrangements. Other analysts (e.g., Brotherston 1976; Coe 1965; Coggins 1980, 1988c; Marcus 1973; Roys 1967; Schele and Freidel 1990:66-77) have discussed symbolism of cardinal orientations in settlement patterns, ritual behavior, and other aspects of Maya culture. Notably, they have tended to infer the primacy of the east-west dimension (especially as the path of the sun's movement) in structuring spatial relations, and the paramount importance of east as the direction associated with strength and potency. They have noted frequently, for example, that sixteenth-century maps placed east at the top, where we would conventionally place north. The present paper does not contradict these previous arguments, but contends that a north-south dimension was recognized anciently in addition, and constitutes part of an evolving exploration of the potential symbolic meanings associated with that dimension.

More specifically, this research centers on a particular set of site-planning principles involving cardinal directions, as outlined elsewhere in some detail (Ashmore 1986, 1987a, 1987b, 1989a; Coggins 1967). It is only one of multiple such sets, or spatial templates, recognized in Maya sites (Ashmore 1986; Freidel 1979; Freidel et al. 1990; Matheny 1987) but is one whose presence has been identified in various Maya centers from the Late Preclassic (ca. 400 B.C.-A.D. 100) through at least the Late Classic (ca. A.D. 600-900). The template in question combines the following principles: (1) emphatic reference to a north-south axis in site organization; (2) formal and functional complementarity or dualism between north and south; (3) the addition of elements on east and west to form a triangle with the north, and frequent suppression of marking the southern position; (4) the presence in many cases of a ball court as transition between north and south; and (5) the frequent use of causeways to emphasize connections among the cited elements, thereby underscoring the symbolic unity of the whole layout.

Drawing on data and interpretive arguments from various sources (e.g., Coggins 1967, 1980; 


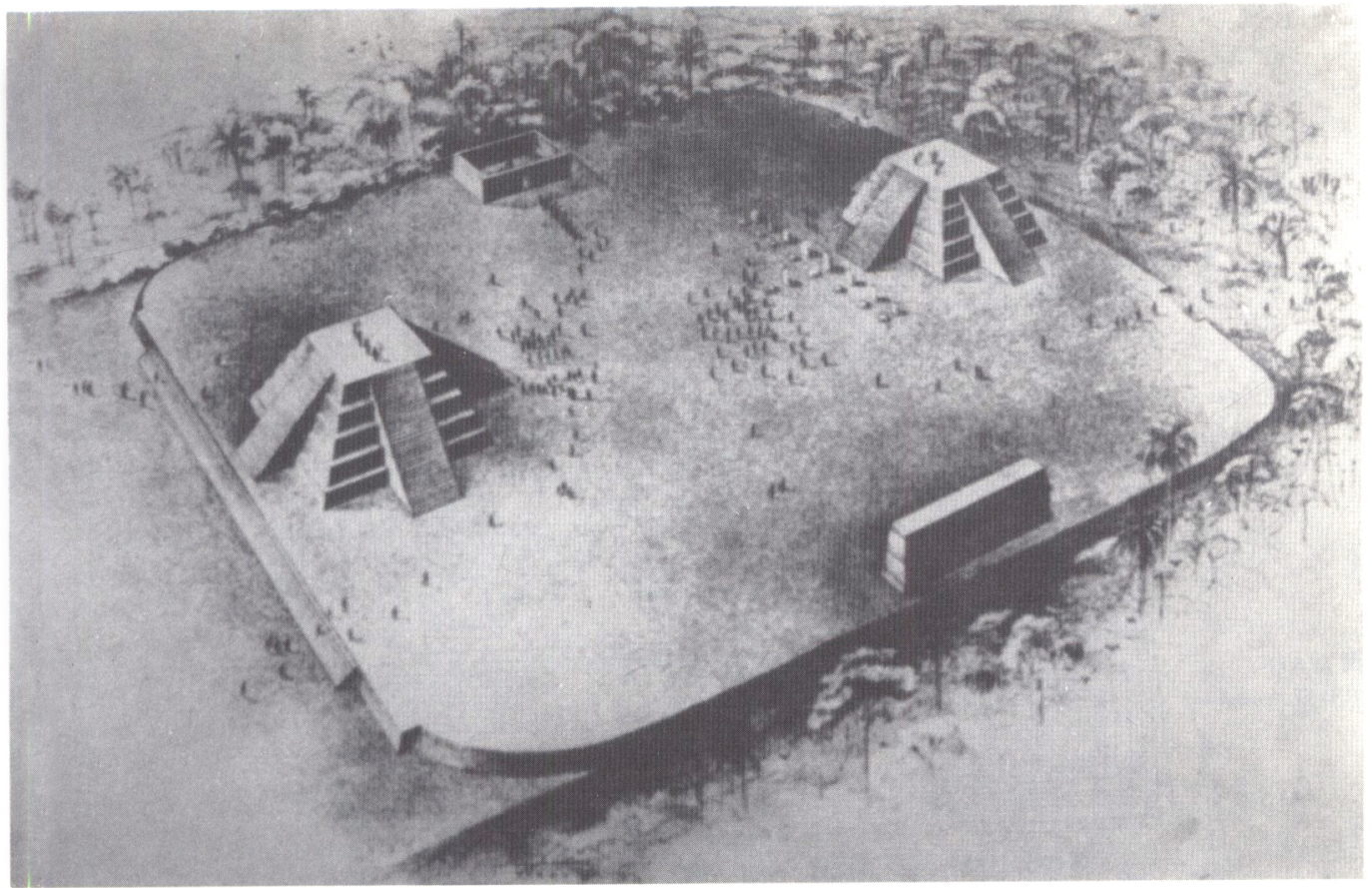

Figure 1. Reconstructed view of Twin Pyramid Complex (Group 4E-4), Tikal, Guatemala (illustration by Norman Johnson, reproduced courtesy of the Tikal Project, The University Museum, University of Pennsylvania).

Freidel 1981; Gossen 1974; Guillemin 1968; Schele and Miller 1986; Tedlock 1985), this set of principles was linked to the following ancient cosmological concepts, some of them pan-mesoamerican (Ashmore 1989a): (1) a multilayered universe, with a sky of many levels in which the royal ancestors lived, and a watery underworld below the natural world, likewise with multiple layers, where supernaturals lived and which served as the setting for the primordial ordeals of mythological Hero Twins; (2) the unification of these layers in time via the cycles of the sun, moon, Venus, and other celestial bodies; (3) vertical connections in space between the natural world and the supernatural domains-for example, via the four bacabs holding up the corners of the sky, mountains mediating between sky and earth, or caves linking the earth with the underworld; and (4) a division of the world in four parts apparently corresponding to cardinal directions (see below), plus a central position, each part with its diagnostic color and distinctive life forms.

The postulated articulation of architectural form and its inferred cosmological meaning (hereafter referred to jointly as "the model") is best exemplified in the Twin Pyramid Complexes of Tikal (Figure 1; Coggins 1980; see also Ashmore 1989a; Jones 1969). In these complexes, pyramids flank east and west sides of a spacious plaza; one interpretation viewed the pyramid terraces as steps used by the sun in its daily transit through the sky (Guillemin 1968). Bounding the south of the plaza is a single-room building with nine doorways, thought to stand for the underworld with its Nine Lords of the Night. Opposite this building, on the north, is an unroofed enclosure housing a single stela and its altar. If south is symbolically the underworld and "down" in these groups, then north must be "up," or the celestial supernatural realm. The ruler portrayed on the northern stela thereby symbolically becomes supernatural by placing his portrait in the northern position-that is, he ascends to the sky and is equated with his ancestors (e.g., Coe 1988:235; Miller 1985:7-8; Swiat 1990). ' For the moment, however, the point is the provisional interpretation of each complex as a map of the universe, a microcosm, with the ruler placed in a position of consummate power. Both the Twin Pyramid Complexes and the model underlying them are well-structured expressions of political symbolism. 


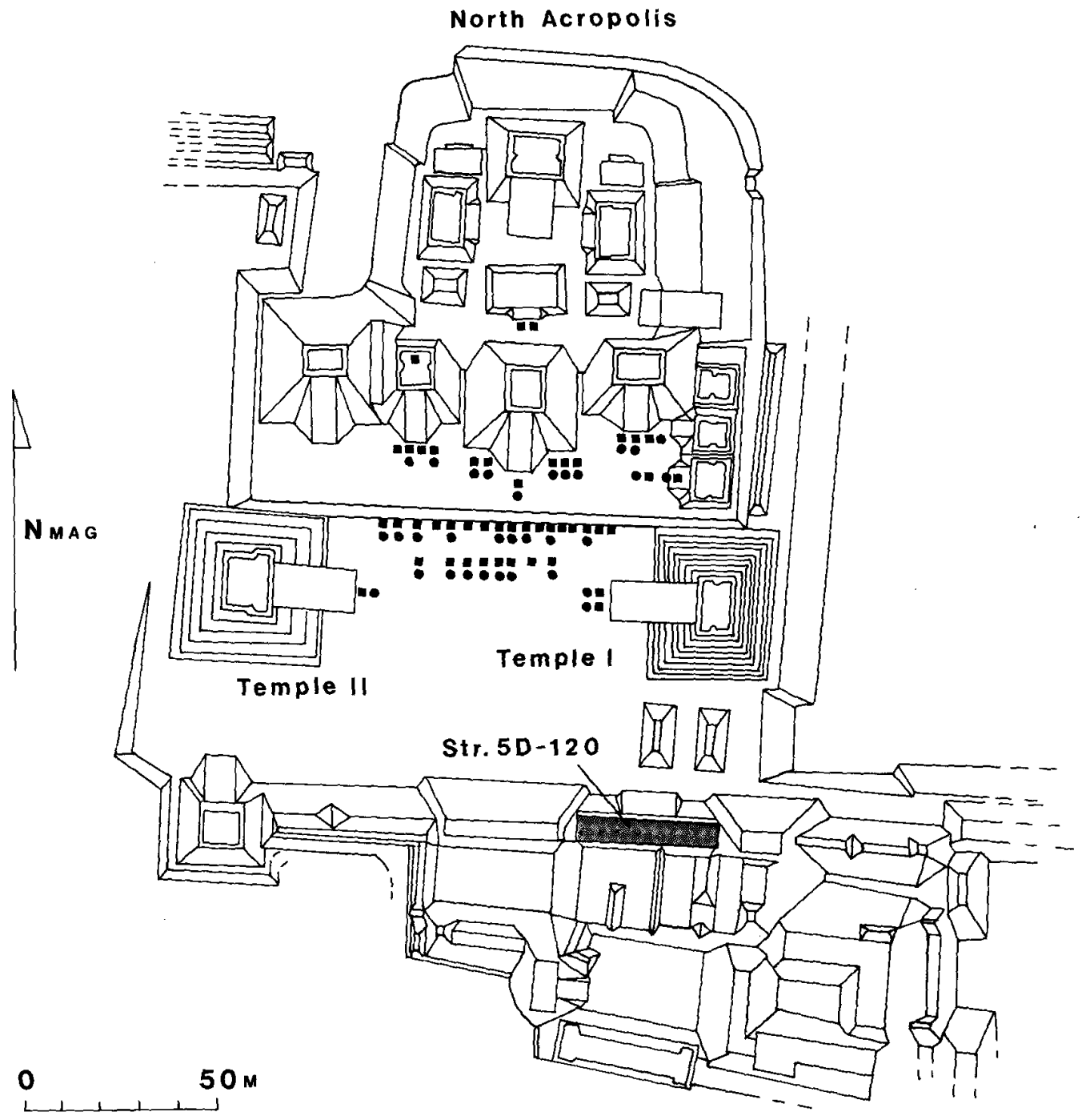

Figure 2. Plan of Great Plaza area, Tikal, Guatemala, highlighting architectural features cited in text. Solid black symbols are stelae and altars. (Redrawn after Tikal Report No. 11 [Carr and Hazard 1961] and Coe and Larios [1988], courtesy of the Tikal Project, The University Museum, University of Pennsylvania; inking by C. Carrelli.)

The same model, with the addition of a ball court, is repeated in the Great Plaza area of Tikal (Figure 2; Guillemin 1968). Temples I and II are the east and west pyramids, Str. 5D-120 (with its nine doorways) marks the south, and the North Acropolis, with its royal tombs and stelae, occupies the north. On an even grander scale, and likewise with a ball court at center, the model accounts for the placement of the largest constructions of Ruler B, Yax Kin Caan Chac (Ashmore 1987a, 1987b, 1989a). In the latter case (Figure 3), west and east are, respectively Temples IV and VI (also called the Temple of the Inscriptions), while a Twin Pyramid Complex, Group 3D-2, occupies the north. ${ }^{2}$ Indeed, in this expression of the template, the ruler is doubly placed in the heavens, for his portrait occupies the northern element (stela in the enclosure of Group 3D-2) of a larger northern element (Group 3D-2 in the larger arrangement). The south is either marked by Str. 5D-120 or left apparently unmarked, and understood to lie below the earth's plane, literally in the underworld; 


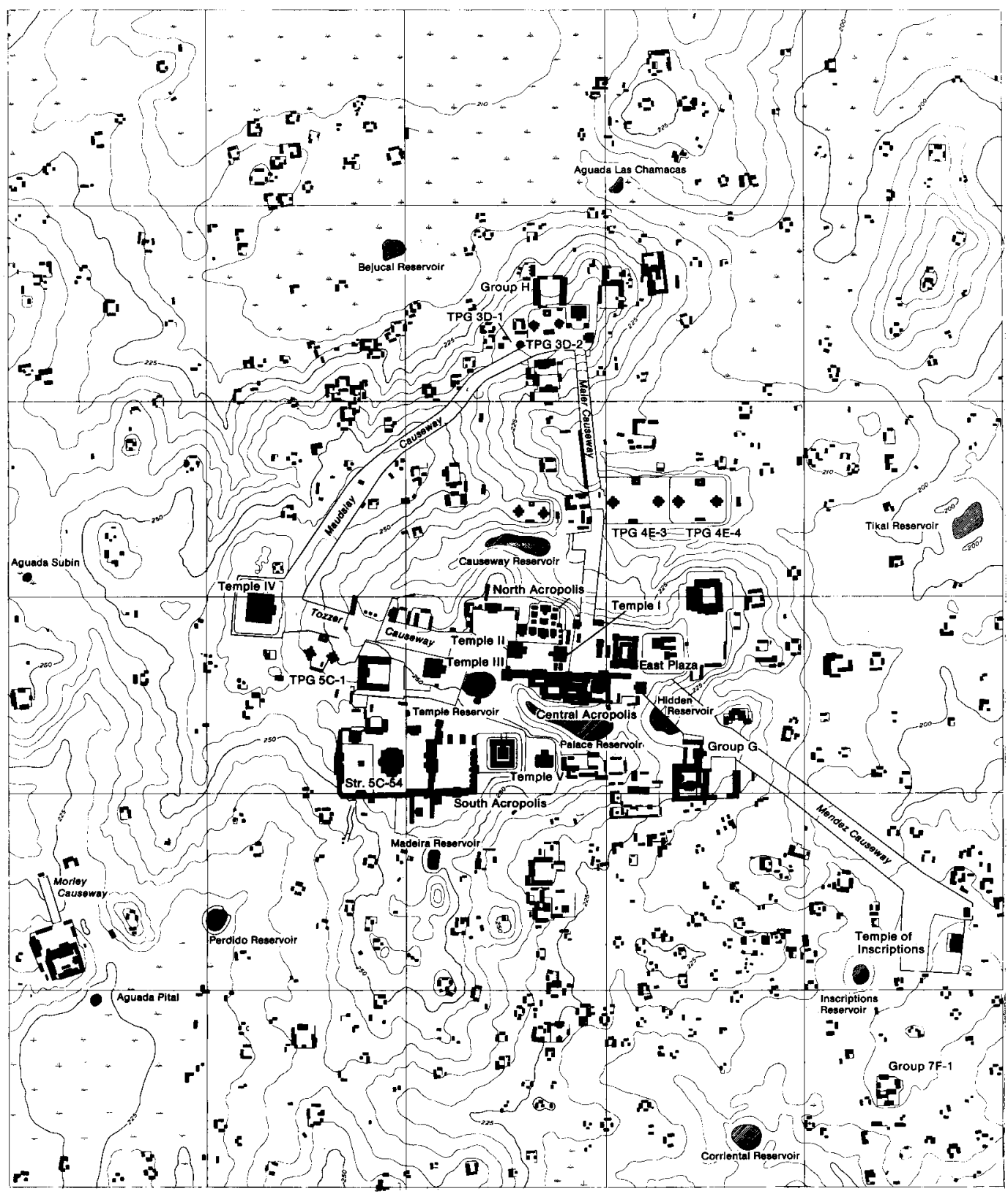

Figure 3. Map of Tikal, Guatemala. Grid squares are $500 \mathrm{~m}$ on a side and oriented to magnetic north. (Reproduced courtesy of the Tikal Project, The University Museum, University of Pennsylvania.)

such implicit but archaeologically "invisible" marking is compatible with Maya artistic conventions in other media, such as the "stacking principle" recently described by Freidel and his colleagues (Freidel 1981:218, 1986; Freidel et al. 1991; see also Schele and Miller 1986). Like the Twin Pyramid Complexes, these other Tikal arrangements are interpreted as political assertions, equivalent in content (linking the sovereign to symbolically powerful positions) though more imposing in scale.

Several microcosmic arrangements may also be present at Copán during its Late Classic peak (Figure 4). The largest appears similar to the grand plan at Tikal, and again a ball court (here, within 


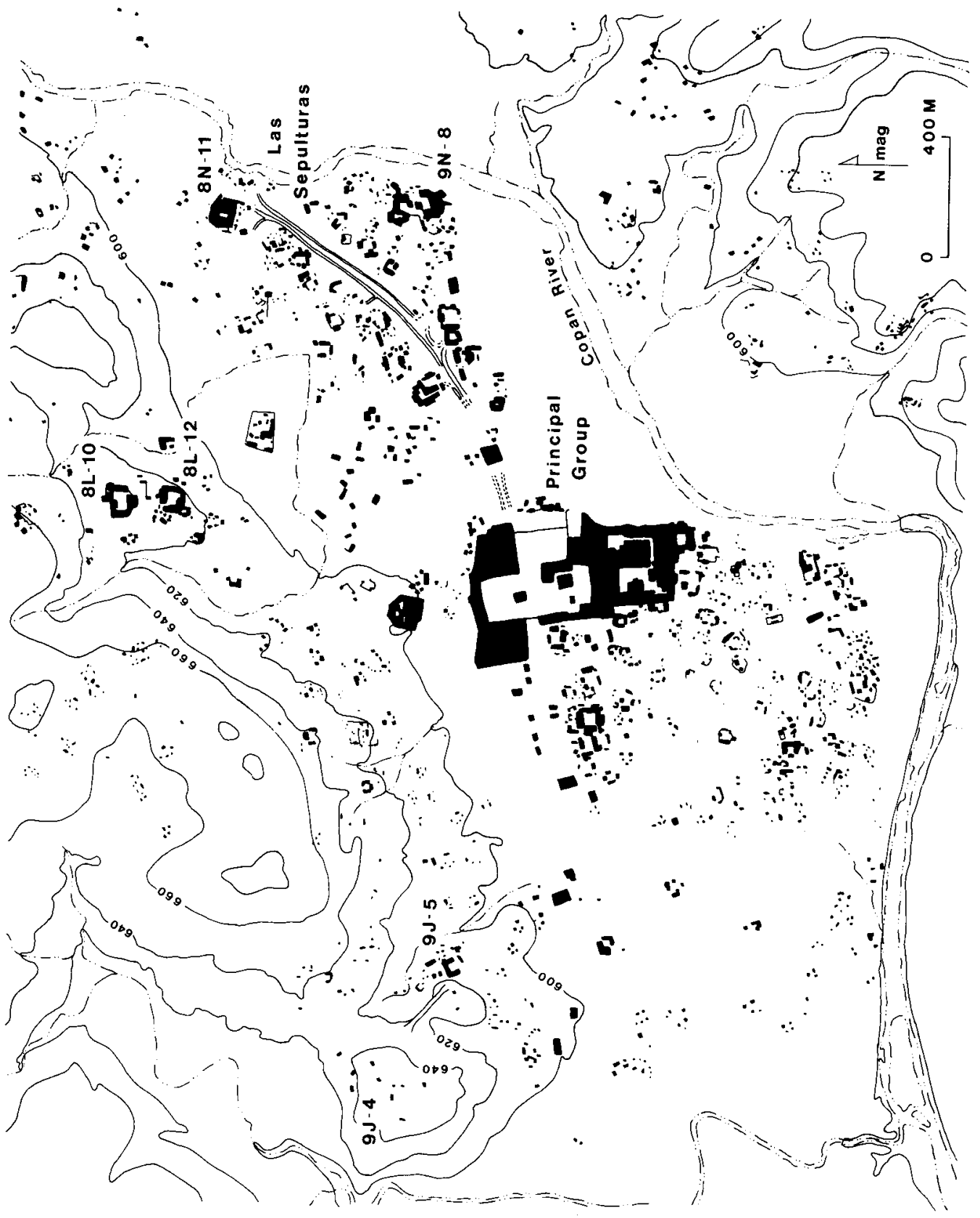


the Principal Group) occupied the center. East, west, and north points were occupied by imposing architectural groups, each approximately $1 \mathrm{~km}$ from the ball court. In Copán, these groups are, respectively, Groups $8 \mathrm{~N}-11,9 \mathrm{~J}-4$ and $9 \mathrm{~J}-5$, and $8 \mathrm{~L}-10$ through $8 \mathrm{~L}-12$. South may have been unmarked, although the Acropolis (discussed below; see also Miller 1988), the Copán River (Julia Miller, personal communication 1990), and/or a small complex with frog sculptures, south of the river (Eleanor King, personal communication 1990), might have stood for this watery underworld position. ${ }^{3}$

Copán's east and west groups are linked to the center by the only causeways known in this area, a $25-\mathrm{km}^{2}$ pocket of the Copán River valley (see below and Fash 1983b). Moreover, at the east end of this pocket, Linda Schele and Nicolai Grube (1988) have identified a reference to an "east quadrant" on Copán Stela 13. Stela 19 may mark another such "quadrant," this time in the west (Grube and Schele 1988). These texts and the causeways appear to support the previously cited contention that a conceptual east-west axis existed among the ancient Maya, at least at Copán; no equivalent stelae are known in northern or southern positions there.

It is important to note that the foregoing interpretations were developed with data collected for other investigative reasons. Before 1988, with one partial, non-Maya exception (Ashmore 1985, 1987c), neither excavation nor other investigation had been undertaken specifically to explore this or any similar site-planning model. The Copán North Group Project (Proyecto Arqueológico Copán de Cosmologia) was therefore created, by contract with the Instituto Hondureño de Antropologia e Historia, primarily to examine the symbolic implications of the model described here, by means of excavations in the northern architectural groups at Copán. For this reason, Groups $8 \mathrm{~L}-10$ through $8 \mathrm{~L}-12$ are referred to hereafter, collectively, as the "Copan North Group." If the directional associations of the model are valid, the northern position stood specifically for the sky, where the sun crossed at midday and where the royal ancestors resided (Ashmore 1987a, 1987b, 1989a). One would then expect archaeologically to encounter in the North Group material indices of symbolism pointing to celestial, royal, ritual, and "northern" associations. Because of the multiple and often redundant forms and media of Maya symbolism, the manifestations of these themes were predicted only to the level of specifying that (1) genres in which symbolic expression was likely (e.g., sculpture, hieroglyphic texts, and ritual deposits [caches and/or burials]) should be encountered, and (2) the finds should preferentially involve the cited north-linked themes.

This project constitutes the first archaeological evaluation of the existence and symbolic associations of ancient Maya concepts of direction. No claim is made here that the evaluation has been definitive. Among other things, the samples of all data categories are small, and it is not always clear how the expectations of the model might be unambiguously falsified by further testing. Nevertheless it would appear that (1) the material symbols encountered by the project are remarkably tightly patterned in their observable characteristics, and (2) the most parsimonious interpretation of the patterns, at present, is that offered by the model (see Kelley and Hanen 1988). Although some of the interpretations offered below are frankly speculative, they are presented as formulations for further exploration, in the North Group or other settings. Indeed, concurrent with the cited archaeological research, other scholars have continued exploration of linguistic, epigraphic, and other data concerning representation and significance of directionality in the Maya world (Bricker 1983, 1988; Closs 1988a, 1988b; Coggins 1986, 1988a; Grube and Schele 1988; Miller 1988; Schele and Grube 1988). These independent perspectives are considered below, following summary of project results.

\section{COPAN AND THE NORTH GROUP PROJECT}

Copán is a major Maya center in the highlands of western Honduras. Known to outsiders since the sixteenth century, the main ruins have long been considered among the most beautiful archi-

Figure 4. Map of eastern part of Copán Valley pocket, highlighting Groups $8 \mathrm{~L}-10$ and $8 \mathrm{~L}-12$ and other features discussed in text. (Redrawn after Fash and Long [1983], courtesy of the Instituto Hondureño de Antropologia e Historia and William L. Fash; inking by C. Carrelli.) 
tectural and sculptural monuments of the ancient Americas. Archaeological excavations have been conducted intermittently since 1834 (e.g., Gordon 1896; Longyear 1952; Morley 1920), and some half-dozen interrelated research projects have operated continuously there since 1975 (e.g., Baudez 1983; Fash 1988; Fash and Fash 1990; Fash and Stuart 1991; Sanders 1986, 1990; Webster and Gonlin 1988; Willey and Leventhal 1979; Willey et al. 1978). Precolumbian occupation extends in time from the Early Preclassic (ca. 1000 B.C.) through the Postclassic (after A.D. 900), with the date and timing of local decline being a subject of current debate (Webster and Freter 1990a). Within that overall span, the local dynastic record opens in the mid-fifth century A.D. with the dynasty's founder, Yax K'uk M'o, and apparently ends rather abruptly in 822, when a little-known ruler succeeds Yax Pac, the sixteenth and last great sovereign (Fash and Stuart 1991; Grube and Schele 1987). The bulk of settlement remains in the region occupy a $25-\mathrm{km}^{2}$ pocket of the Copán River valley, where rich alluvium and adjacent hillslopes supported an agricultural population estimated to have reached a Late Classic peak of about 9300-11,500 (Webster and Freter 1990b). Epigraphic, iconographic, and other studies have combined with archaeological research to document in rich detail Copán's political, demographic, and economic development, on which new discoveries and insights continue to emerge on what sometimes seems a daily basis.

Groups 8L-10 through 8L-12, collectively designated Copán's "North Group," are located in the "Salamar" sector of the Copán pocket (Figures 4 and 5; Fash and Long 1983). Within this sector is Morley's "Group 6" (mislabeled as Group 5 on his 1920 map), which he described as "a small group containing a very elaborately sculptured temple, which, judging from the fragments lying around, must have been one of the most beautiful in the valley" (Morley 1920:13). The latter statement surely pertains to Groups $8 \mathrm{~L}-10$ and/or $8 \mathrm{~L}-12$ specifically, though equally surely much of the sculpture observable at that time has since been removed by persons unknown. Together, these groups occupy a natural promontory overlooking the Principal Group and much of the surrounding valley. On the surface, the imposing compounds appear to be elite residences, like Group $9 \mathrm{~N}-8$ in the Sepulturas zone (Webster 1989; Webster et al. 1986).

A decade ago, the Harvard University Copán Project tested the plazas of the two larger groups, indicating that occupation in both was brief, late (Late Classic Coner ceramic complex; ca. A.D. 700-?900), and relatively uncomplicated in constructional development (William Fash, personal communication 1986). Fragments of sculpture from fallen facade mosaics were noted near Strs. 8L74 (Group 8L-10) and 8L-87 (Group 8L-12). In February 1988, AnnCorinne Freter excavated another 12 test pits in and around Group $8 \mathrm{~L}-10$, as part of Operation XL of the Proyecto Arqueológico Copán (PAC), and artifacts she recovered indicated that the complex had served as residence to a noble family (A. Freter, personal communication 1988). A single fallen element of mosaic sculpture was recovered, north of Str. $8 \mathrm{~L}-73$.

The Copán North Group Project conducted 13 weeks of fieldwork in 1988-1989. As PAC Operation XLII in both years, project personnel completed a total of 49 test excavations. Because of permit provisions, excavations neither penetrated substructure masses nor cleared superstructure plans. Work focused instead on plazas of the two groups (i.e., on and within the construction of platforms supporting the compounds) and areas just outside the groups (e.g., middens, areas of tumbled construction). Information was sought on the dates of construction and occupation for each group, as well as any and all activities carried out there. The latter goal emphasized, but was not limited to, seeking remains of ancient symbolic declarations, especially in the form of sculpture and/or ritual deposits. The purposive sampling strategy therefore focused attention on excavation forms and locations deemed maximally likely to discover such materials. For caches and burials, test pits probed building or stair corners and central axes exterior to the construction proper; for sculpture, excavations cleared along building sides. The resulting excavation sample clearly remains limited in some important respects (e.g., ritual deposits may well remain undiscovered within

Figure 5. Plan of Copán North Group (Groups 8L-10, 8L-11, and 8L-12). Key buildings are labeled, as are locations of major burials $(B)$ and caches $(C)$ discussed in text. Full designation includes the map prefix $8 \mathrm{~L}$ - for 


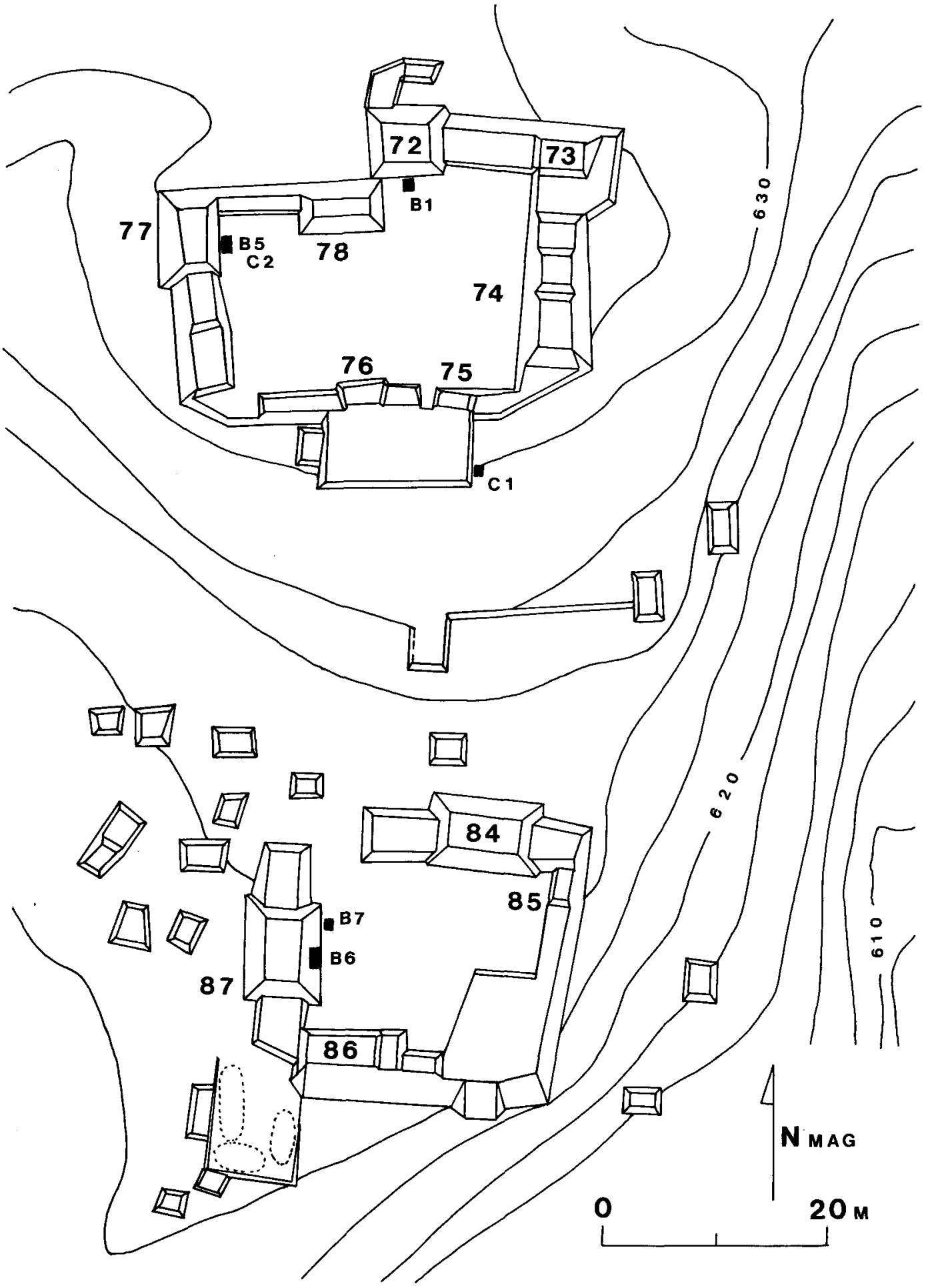

building numbers and operation number XLII- for burials and caches. (Redrawn, with amendments, after Fash and Long [1983], courtesy of the Instituto Hondureño de Antropología e Historia; inking by C. Carrelli.) 


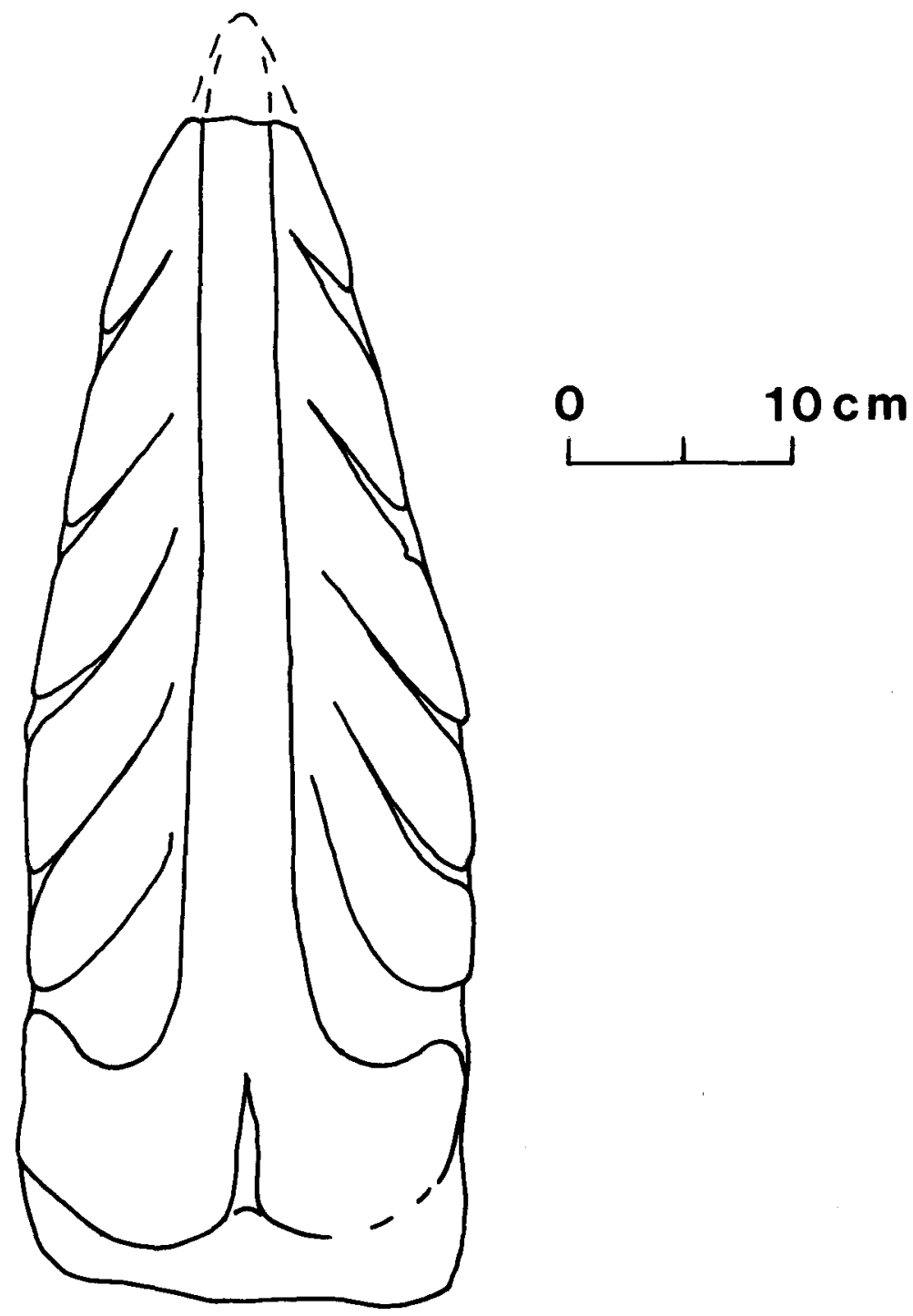

Figure 6. Sculpture from Str. 8L-74, Copán, depicting stingray-spine bloodletter (CPN 15031; inking by C. Carrelli).

building masses). Nevertheless, as asserted earlier, the patterns observed in extant data sets suggest provisional interpretations useful to stimulate discussion and to guide further excavations, here and elsewhere.

The following paragraphs review the data most directly pertinent to the model, as recovered from the two larger units, $8 \mathrm{~L}-10$ and $8 \mathrm{~L}-12$, of the Copán North Group (see Ashmore, comp. [1988, 1989] for more complete data summaries). In both, abundant evidence testified to domestic occupation in the Late Classic. Such artifacts as manos and metates represented food-preparation activities, and analysis of the chipped-stone remains has isolated distinct areas of production for obsidian and chert implements (Gajewski 1988, 1989). Ceramic forms likewise accord with residential use, and domestic middens were found in each group. The most marked contrasts between the two compounds, however, and the evidence bearing on the model lie in their sculpture, caches, burials, and perhaps architectural forms. 


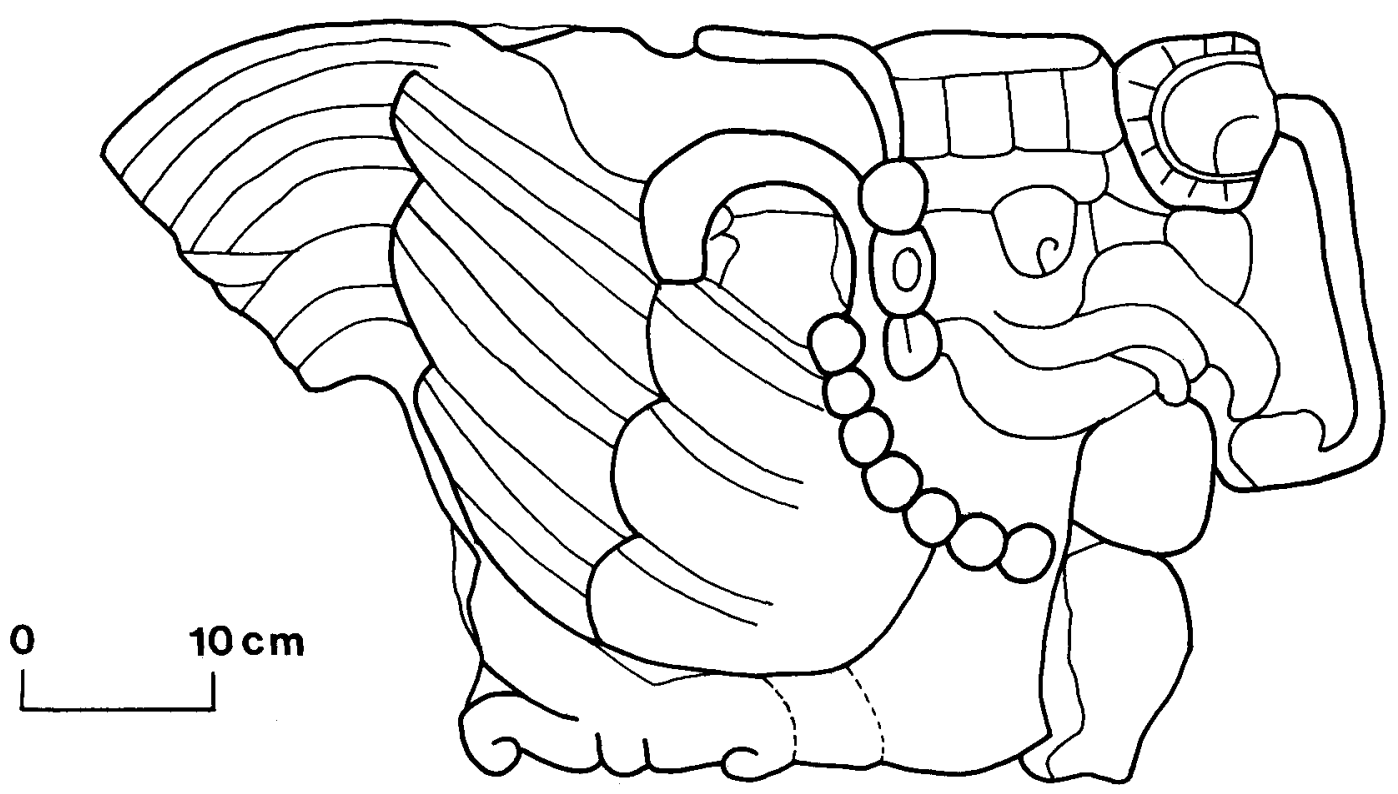

OP.XLII

CPN. $\# 15058$

\section{Copan Ruinas}

Figure 7. Sculpture from Str. 8L-74, Copán, depicting bird tentatively identified as Vucub Caquix or Seven Macaw (Tedlock 1985) (CPN 15058; drawing by J. G. Arias; inking by R. Murcia).

\section{Group $8 L-10$}

In Group 8L-10, 89 fragments of sculpture were recovered from around Str. 8L-74. While this total is considerably smaller than the 231 pieces recovered from Str. 9N-82 (Fash 1986:340)-the "Scribe's Palace," in the Sepulturas zone-the contrast is probably due in part to quite different degrees of clearing in the two locations, and perhaps to greater stone robbing at Str. 8L-74 (see above). The spatial distribution of sculptural motifs is also distinct in the two locations. That is, contrary to the pattern of bilateral symmetry in motifs at Str. $9 \mathrm{~N}-82$ and other buildings at Copán (e.g., Fash 1986, 1989), the distribution from Str. 8L-74 is not symmetrical along the length of the facade from which they had fallen. Clustering of motifs suggests the presence of two distinct buildings.

One inferred building appears to have borne sculpture with themes of sacrifice, ritual, and reference to the heavens. Sculptural icons included a stingray-spine bloodletter (Copán sculpture inventory number CPN 15031; Figure 6), large deity masks (e.g., CPN 15000), and a jewel-bedecked bird (CPN 15058; Figure 7), thought to represent Vucub Caquix, a form of the Principal Bird Deity discussed by Bardawil (1976) and Taube (1987). ${ }^{4}$ These motifs are more reminiscent of decoration on buildings with ritual function in the Principal Group (e.g., Fash 1988) than on known elite residences elsewhere in the community (e.g., Webster 1989).

Farther north, but supported by the same substructure platform, was another building, the facade of which carried a hieroglyphic text (Figure 8), rendered in a distinctive medallion-like sculptural form. The text includes a calendar- round date, 8 Lamat 6 Tzec, most likely corresponding to Maya long-count positions of 9.15.6.14.8, 9.17.19.9.8, or perhaps 10.0.12.4.8 (see below). (Using the 584,283 correlation, these dates correspond to Gregorian equivalents of 3 May 738, 20 April 790, and 7 April 842.) The same text also mentions the name of a Copán ruler, known as 18 Jog or 18 Rabbit, who was captured by Cauac Sky of Quiriguá on 9.15.6.14.6 (1 May 738), and beheaded 

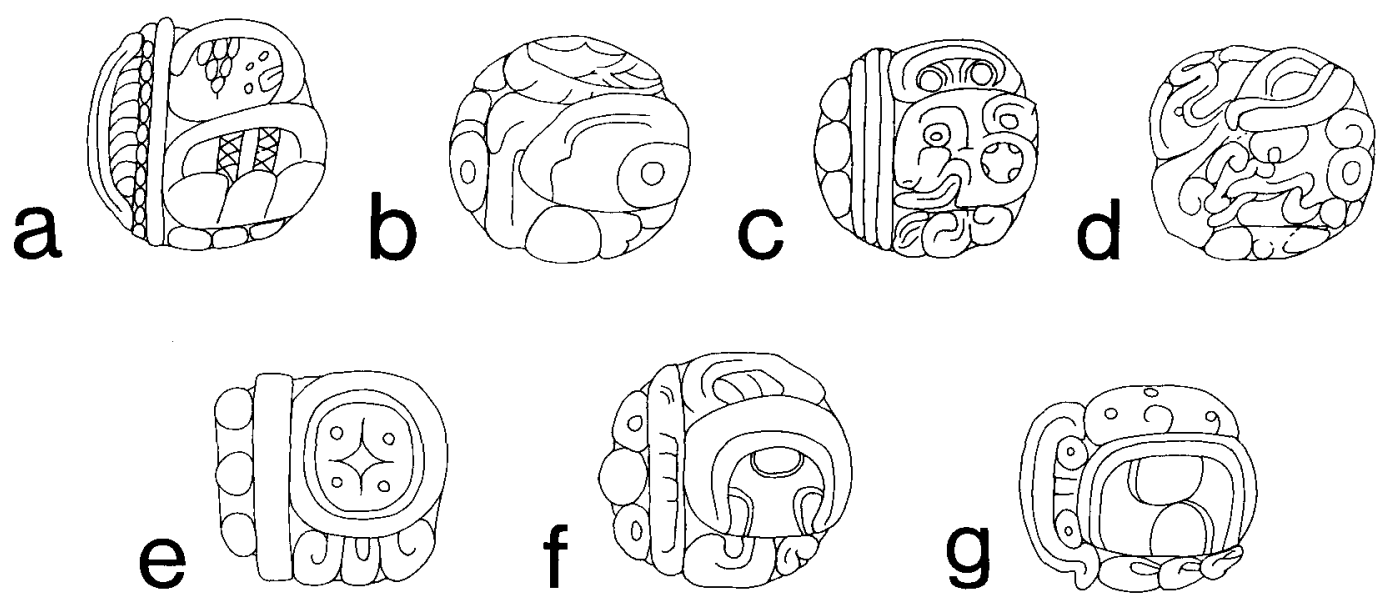

Figure 8. Fallen facade text elements $(a-g)$ recovered from west side of Str. 8L-74, Copán. Medallions are each $26-31 \mathrm{~cm}$ in diameter (see text for CPN numbers; inkings by C. Carrelli).

probably on the same date (e.g., Fash and Stuart 1991; Miller 1988:166; Schele and Miller 1986: 252; Schele et al. 1989:4). ${ }^{5}$ The text remains incomplete, but from their relative positions as fallen along the west side of Str. 8L-74, the north-to-south (i.e., reading) order of the seven recovered medallions is as follows: elder brother (CPN 15011; deciphered by Stuart [1989b]; Figure 8a), house (CPN 15001; otot; Figure 8b), 18 Rabbit (CPN 15076; Figure 8c), God K (CPN 15006; Figure 8d), 8 Lamat (CPN 15064; Figure 8e), 6 Tzec (CPN 15021; Figure 8f), hel (CPN 15054; Figure 8g). ${ }^{6}$ William Ringle (personal communication 1991), among others, suggests the inscription likely serves to identify the building as the house of one of 18 Rabbit's relatives. The string of medallion sculptures also included portraits of deities of the sun and moon, though these were not discovered archaeologically (see Note 6). For the moment, the most important observations about the data from "Str." $8 \mathrm{~L}-74$ are (1) the presence of an inscription referring to an act or event involving the ruler 18 Rabbit, probably already deceased, or his brother; (2) the juxtaposition of a pair of opposites (the buildings with contrasting facade programs) on a north-south axis; and (3) an elaboration of abstract themes in both sets of sculpture, with a corresponding lack of personal portraiture or other representation of individuals living in the compound. These points are discussed further below, along with speculations on the overall content of the incomplete text.

Two caches were encountered in Group 8L-10. Cache XLII-1 was located in what was thought a likely place for a ritual deposit, adjacent to the southeast corner of the frontal stair on the south side of the compound. It comprised a single hemispherical stone covered by stone slabs, with a deer humerus lying atop the slabs. The significance of this cache is still obscure, but a possible interpretation is outlined below. Cache XLII- 2 was located on the east or front side of Str. 8L-77 and its tomb, Burial XLII-5, described below. This cache consisted of a ceramic box containing a small Spondylus bivalve and a stingray spine. The lidded box is reminiscent of, though not identical to, others known from Late Classic caches at Quiriguá (e.g., Bullard and Sharer 1991; Stromsvik 1941).

Five burials were encountered in Group 8L-10 (Carrelli 1990). Three (XLII-2, -3, and -4) were simple interments, each placed below the edges of the plaza and an adjoining platform. The other two burials were tombs, each housing a pair of occupants, probably of elite status, in a chamber with long axis north-south and centered on the principal axis of a building. In each case, a woman lay to the north of a man (Rebecca Storey, personal communication 1988).

The smaller of the two tombs was Burial XLII-1, in front of Str. 8L-72, on the north side of the plaza. At plaza level, the tomb location was marked by a small, uncarved round "altar." The only artifacts in the tomb were a pair of flat jade pendants, one found with each skeleton. 

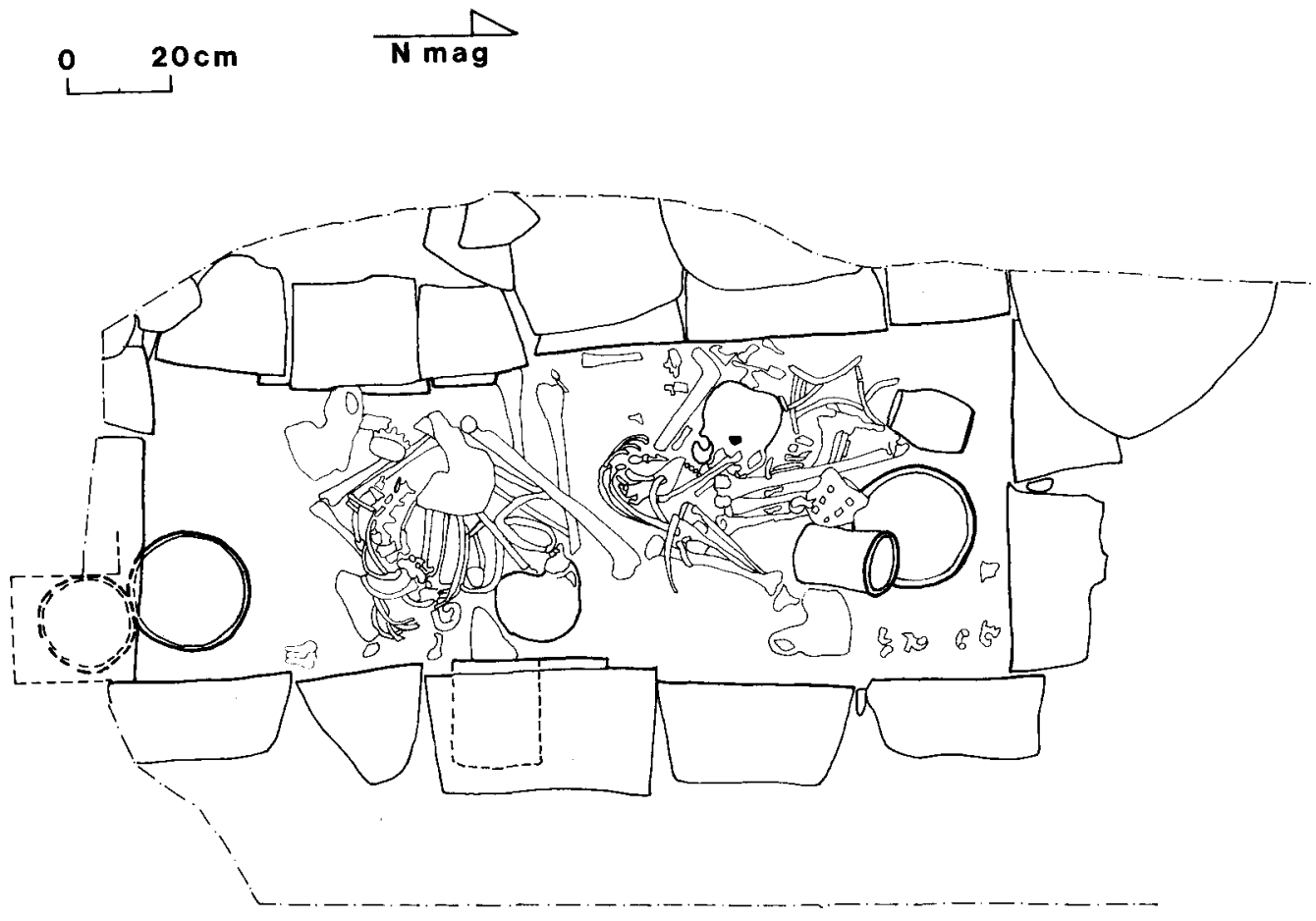

Figure 9. Plan of Burial XIII-5, Copán (drawing by A. Pezzati; inking by R. Murcia).

The second tomb, Burial XLII-5 (Figure 9) was located in front and on the center line of Str. 8L77 , on the west side of the plaza. This tomb was signaled by an uncarved square "altar," and in plaza fill below the altar, by Cache XLII-2, with the ceramic box mentioned above. Fragments of a third human cranium (plus loose jade-inlaid teeth) were found with the two complete skeletons, along with a bone bead, a broken shell ring, two spindle whorls, and five vessels-four of the Late Classic Surló ceramic type common in Copán burials of this period (Coner complex; Viel 1983) and the fifth an import, a pear-shaped Pabellón Molded-carved vessel (Sabloff 1975; see below).

Although "double" tombs are not unique to Group 8L-10, they are unusual at Copan, and those of the North Group are particularly so in pairing adults of seemingly equivalent social status (i.e., neither is clearly "attendant" or subsidiary to the other) without evidence of sequential interment (i.e., in a reused tomb) (Carrelli 1990). Among other tombs reported at Copán to date, the one most reminiscent of the Group 8L-10 double tombs appears to be Gordon's Tomb 6. In fact, from Gordon's (1896:32) report, it appears that this tomb was encountered somewhere near the North Group, although the original description of location is too vague to be certain (Carrelli 1990:119120; Longyear 1952:42-43). Not only are these tombs unusual within the funerary corpus, the two discovered in Group 8L-10 repeat the pattern of paired opposites on a north-south axis. Such pairing was thus present on the three sides of the compound most elaborated in terms of architectural volume and investment - the east, west, and north sides - with the south side apparently left open or vacant. ${ }^{7}$ Although the exact pairings differed, with interments in two locations and buildings in a third, the forms are plausible allomorphs in the larger category of paired opposites. Moreover, the double tombs (specifically) imply a diminished importance of individual identity: that is, as cited above, no single decedent is clearly the focus of mortuary ritual, and either (or both) could as plausibly have been sacrificial offerings, perhaps for individuals interred within the buildings adjacent to the tombs (see also Group 8L-12, Burial XLII-7, below). The latter inference could be a test implication for future excavations (see concluding discussion); currently, however, the tombs of 
Group 8L-10 parallel the sculpture from Str. 8L-74 in embodying themes more abstract or impersonal and ritual oriented than aimed at commemorating an individual.

\section{Interpretation of Group 8 L-10 Symbolism}

It is worthwhile considering further these notions of paired opposites, of their north-south axis, and of the association of the ends of the axis with different genders. In the first place, in hieroglyphic inscriptions paired opposites are an alternative form for the hel glyph (Riese 1984; Thompson 1971: 161-162; see Figure 8g for an example of the hel glyph). ${ }^{8}$ The complex of concepts conveyed by these forms includes change, succession, completion, and unification, and I propose that in this instance, all the cited concepts are implied. More concretely, and as will be developed below, I hypothesize that the Group $8 \mathrm{~L}-10$ sculpture and the paired opposites in the two tombs celebrate continuity and perpetuation with respect to 18 Rabbit and his dynasty.

First, what might be the significance of the north-south axis and its association with distinct sexes? Sharon Horan (personal communication 1988) suggested that the First Father and Mother could be the referents of the tomb pairs, by analogy with iconographic interpretation of finds from Palenque. Other possibilities, not necessarily contradicting Horan's suggestion, imply a link with ancient concepts of directionality.

Tomb 12, Río Azul, Guatemala (Adams 1986; see also Bricker 1988:Figure 1; Coggins 1988c), provided important initial clues. In that tomb, directional glyphs were painted on the chamber walls. The glyph for "east" (likin) is on the east wall and is associated with another glyph, kin, which refers to "day" or "light"; the glyph for "west" (chikin), on the west wall, is associated with akbal, or "darkness." On the south, the association for the "south-directional" glyph nohol is a Venus glyph, and Venus is male; and on the north (xaman) is the moon, which "is woman" (Thompson 1971:232).

Elsewhere, at times, but not invariably, the moon-or "woman," or the moon goddess Ixchelis linked with the north (Ashmore, comp. 1988; Thompson 1971). But why here in such an explicitly structured relation with Venus? Why this male deity in particular? What do the two have in common? One possible link is their shared identities as agents of birth. Ixchel is well known as the goddess of childbirth, and Venus can be linked to supernatural rebirth. For example, in the Popol Vuh, the Quiché Maya creation myth as recorded in the sixteenth century (Edmonson 1971; Tedlock 1985), it is Xbalanque, the Hero Twin who later becomes Venus or the night sun (e.g., Schele and Miller 1986:245, 306, Note 3; Tedlock 1985:297), who successfully restores his decapitated elder brother, Hunahpu, to life. ${ }^{9}$ The moon/Ixchel also could signify a king's mother, in her role in facilitating the apotheosis of her son, as seen in apotheosis settings at Palenque (Schele and Miller 1986:272, 275). In the context of Tomb 12, Rio Azul, then, the four "directions" would correspond, on the eastwest axis, to the perpetual cycle of the sun's life and death, and on the north-south axis, to the perpetual action of human or divine agents responsible for maintaining the former cycle. Together the tomb walls and their glyphic texts define dimensions that collectively encompass the universe in space (the "directions") and time (perpetual cycles).

The foregoing suggests an analogous symbolic identification for the males and females of the Group $8 \mathrm{~L}-10$ tombs. That is, the tombs' emphasis on the north-south axis may imply not solely the general ideas of "change" and "transition," as signified by paired opposites throughout the compound. Through symbolic reference to Ixchel and Xbalanque, the tombs may also refer to transition specifically by rebirth, perhaps by apotheosis, of individuals identified elsewhere in the group as within the royal dynasty. The parallel of death by decapitation, for both Hunahpu (e.g., Tedlock 1985) and 18 Rabbit (e.g., Schele et al. 1989:4), may likewise be significant, in linking the tomb symbolism to the Str. $8 \mathrm{~L}-74$ text, though decapitation was apparently a preferred means of execution for royal captives (e.g., Schele 1984). ${ }^{10}$

Recall that, for the Maya, there is a close association between the moon and the rabbit, the latter perceived as the figure contained within the celestial "face" of the moon's sphere (Schele and Miller 1983:45-46). There is likewise a strong relation between the rabbit and Xbalanque, for it was by means of a rabbit, imitating a ball, that Xbalanque revived Hunahpu (Edmonson 1971:122-127; 
Tedlock 1985:43, 143-147). However, it is also possible these implied associations do not refer solely to 18 Rabbit as an individual. That is, perhaps this king, by his name, stood for the concept of rulership and dynastic succession. Perhaps too, this king received his name as more of a title, signifying accession (e.g., Laporte and Fialko 1990; Schele and Miller 1983) and the continuity of the dynasty. Glyphic references to Maya rulers, commonly used by scholars as names, are increasingly seen as tantamount to titles (see also Gillespie [1989:170], concerning Motecuzoma as an Aztec title), and it is noteworthy that the "name" of this king (as well as some others) is God K, a deity symbolizing royal authority. ${ }^{11}$

After making the preceding assertions, I discovered Dieter Dütting's earlier epigraphic and astronomical analyses, from which he concluded the following (Dütting 1985a:113; emphasis added; see also Carlson 1980; Dütting 1985b; Lounsbury 1976):

I explored whether accession dates of Maya lords and dates of other historical events were linked with similar dates of the past, with important dates in the life of parents and forefathers, by full multiples of time-periods with astronomical significance. It turned out that the Moon and the planet Venus played a particular role in the timing of such events. The corresponding deities are the divinities most deeply involved in the resurrection process.... ${ }^{12}$

The foregoing symbolic links suggest further specific speculations regarding the third skull in Burial XLII-5 and the meaning of Cache XLII- $1 .{ }^{13}$ In Burial XLII-5 (Figure 9), the complete female skeleton was on the north of the tomb, and the complete male skeleton lay south of her, near the center of the chamber. In the southeast corner of the tomb, in the pottery bowl just outside the wall niche, lay badly deteriorated cranial and dental fragments of a third human (gender unknown). Venus and the moon are closely related to the sun in Maya symbolism (as argued above), and Maya rulers were often symbolically equated with the sun, especially at Copán (e.g., Baudez 1985, 1988). It is therefore possible, although clearly not demonstrable, that the third skull represented the decapitated 18 Rabbit, and the fragments were an effigy "stand-in" for the ruler's skull. The possibility that these deteriorated bones could be his actual remains seems small, though their state of preservation is consistent with the probable date of the tomb, a century or more after the decapitation (see below).

Concerning Cache XLII-1, one notes that the ancient Maya saw a close relation between rabbits and both balls (Schele and Miller 1986:252; Tedlock 1985:44-45, 145-147) and deer (Schele and Miller 1983:46-48). This cache links the latter two elements directly, associating a hemisphere (i.e., halved ball) with a deer bone. Similar-appearing stones also occur as natural inclusions in the raw material of some Copán stelae, and sculptors frequently adjusted their designs to accommodate the balls. In one instance, such a stone was incorporated into a text citing 18 Rabbit, used specifically in place of the glyph for "rabbit" in his name compound on Stela D (Schele and J. Miller 1983:49 50; Schele and M. Miller 1986:252). I therefore speculate that Cache XLII-1 constitutes another reference to 18 Rabbit, perhaps the hemispheric form even representing his death by decapitation.

Indeed, this cache may well have been integral to the compound's overall symbolic theme, celebrating transition of rulership and perpetuation of the Copan dynasty. Note, in particular, the cache's location adjacent to the southeast corner of the large-block stair that was likely the main access to Group $8 \mathrm{~L}-10$. The decapitation would have been the prerequisite stimulus for rites of resurrection (i.e., as cause of the royal death), and thus this event marked a behavioral threshold, the liminal point that triggered ritual action. If Group $8 \mathrm{~L}-10$ was the arena in which these rituals were enacted, it would be appropriate that a putative effigy severed head (i.e., the hemisphere in Cache XLII-1) should flank the stair entry, placing the physical embodiment of the death act at the physical threshold for action (e.g., Turner 1974).

Returning to the overarching theme of transition and transformation, certainly Maya (and other mesoamerican) iconography is rich in allusions to these notions. The subjects of change are usually sequential rulers, astronomical phenomena (especially the sun, moon, and Venus), or calendric cycles (e.g., Baudez 1985, 1988; Dütting 1985b; Freidel and Schele 1988a; Gillespie 1989; Schele and Miller 1986; Stone 1985), all of whose orderly replacement or perpetuation was vital to continuity of Maya life. The dedication of one or more architectural complexes to this theme would be perfectly 
in keeping with symbolism in other media. And at Copán, 18 Rabbit was a particularly important ruler in the sequence. His death at the hands of Quiriguá's Cauac Sky (e.g., Fash 1988; Fash and Stuart 1991; Marcus 1976; Schele et al. 1989; Sharer 1978) apparently precipitated a crisis in political stability at home (Fash and Fash 1990; Fash and Stuart 1991). It led to a significant reorganization of governance (Fash and Fash 1990; Fash and Stuart 1991) and was ultimately the stimulus for construction of the great Hieroglyphic Stairway of Str. 10L-26, a monument explicitly extolling Copán's dynastic strength (Fash 1988:161-166). Furthermore, contrary to usual Maya practice, 18 Rabbit's Structure 10L-22 (Fash 1988:160; Stuart 1987, 1989a) was not sealed by the construction projects of subsequent reigns, which in itself suggests unusual attitudes toward this ruler and his monuments (see also Sharer [1978], concerning a parallel situation at Quiriguá involving Str. 1B2 , associated with the ruler who beheaded 18 Rabbit).

Indeed, the last great ruler, Yax Pac, showed what Stuart et al. (1989:2) refer to as a "consistent preoccupation with 18 Rabbit." I believe it was likely during Yax Pac's reign in the late eighth century, when building sculpture arguably became more widespread among nonroyal elite compounds (Fash 1983a), that Str. 8L-74 was built, as part of an architectural assemblage dedicated via multiple symbolic expressions to proclaiming the immortality of this deceased ruler and, through him, the invincibility of the dynasty. ${ }^{14}$ The expressions probably included archaeologically invisible rites, perhaps marked indirectly by the effigy bloodletter of Str. 8L-74 (Figure 6); possibly this involved something akin to a na ceremony, a still little-known ritual sacrifice of captives to commemorate a dead ruler (Schele 1984: 29). Whenever that structure was erected, however, at least some of the North Group's symbolic expressions of continuity were still being made after the dynasty's collapse around A.D. 822 (Grube and Schele 1987).

Why after the collapse? The ceramics of Group $8 \mathrm{~L}-10$ pertain to the Late Classic Coner complex (ca. A.D. 700-?900), and as noted earlier, the calendric date of 8 Lamat 6 Tzec on Str. 8L-74 could be attributed to alternative positions within and beyond the Late Classic. One radiocarbon date is available, 1,450 \pm 80 years (A.D. 420-580 [Beta-29348]); it derives from charcoal in the matrix surrounding Burial XLII-3 and could well come from old wood and/or from secondary burial. ${ }^{15}$ The most informative material for dating the group's occupation, however, is a series of 39 obsidianhydration dates and the one decorated ceramic vessel from tomb Burial XLII-5. The obsidian dates, analyzed by AnnCorinne Freter (Webster and Freter 1990a:71, 79), indicate an occupation from approximately A.D. 703 through 960 . Even taking into account the error factor of \pm 70 years for each obsidian date, however, the series suggests Late Classic occupation lasting until at least the final decades of the ninth century. The ceramic vessel from the primary context of the tomb accords with the obsidian dates inasmuch as the specific type, Pabellon Molded-carved, almost all of which was manufactured in the Pasión region of southwest Petén, Guatemala, first appeared about A.D. 830 (Ashmore, comp. 1988; Sabloff 1975; Webster and Freter 1990a:79, 81). In the ninth century, then, the occupants of Group 8L-10 had authority and resources sufficient not only to obtain such an exotic item of elite culture but also to inter it in an imposing construction. The stingray spine and Spondylus bivalve in nearby Cache XLII-2 suggest bloodletting took place in connection with the interment.

\section{Group $8 L-12$}

Group 8L-12, too, was occupied in the Late Classic, as attested by Coner-complex ceramics (but with mixed remains from the Late Preclassic as well), and a series of 15 obsidian-hydration dates from A.D. 740 to 935 -a span essentially equivalent to that for Group 8L-10. The two compounds were, then, contemporaries in the late first millennium A.D., but they appear to have had important functional differences. Both were domestic sites, at least in part, but there were significant contrasts in other roles, as can be seen in remains of symbolic expression and as implied as well in architectural and settlement form.

In the first place, while there was at least one sculptured facade in Group 8L-12, on Str. 8L-87, this time the theme was personal portraiture. One tenoned sculpture of a human head was recovered, as well as carved fragments from multiple feather headdresses, clothing, and a shield (the shield is 
discussed further below). For now the important implication is that in Group 8L-12 one is dealing with personal references, portraiture, and an iconographic focus on an individual, and in this way Str. 8L-87 is more similar to Str. 9N-82-the Scribe's Palace or House of the Bacabs (Fash 1986; Webster et al. 1986)-than to the neighboring Str. 8L-74.

Two burials were encountered in Group 8L-12, both in association with Str. 8L-87, on the west side of the plaza. Burial XLII-6 was a vaulted tomb the presence of which was marked at plaza level by a large uncarved rectangular "altar" (broken) on the center line of Str. 8L-87. Excavation below that altar encountered the exterior of the tomb, whose chamber lay beneath the substructure of the building. The tomb housed a single adult (probably male; Rebecca Storey, personal communication 1989), with fragments of deer-antler tines, nine ceramic vessels, and five jade ornaments including a line-incised bar pectoral, two other pendants (each carved with a human face), and two ear flares. Seven of the vessels were of Surló type (William Fash, personal communication 1989; Viel 1983) common in Late Classic Copán burials; the other two were another ritual-related type, called Sepulturas (Guillermo Murcia, personal communication 1989; Viel 1983), adorned with effigy cacao appliques. In one of the Surló vessels were two shells, one of Spondylus and the other, Strombus. The former shell contained two miniscule stingray spines. It is important to note that, as in the sculpture from this structure, evidence points to ritual celebration of an individual person, not of abstract ideas as found in symbolic expressions from Group $8 \mathrm{~L}-10 .^{16}$

Burial XLII-7 was east of Str. 8L-87 and north of the altar marking Burial XLII-6. Its location too was signaled at plaza level, by an uncarved square "altar" set atop a line of flat-laid slabs. The burial itself consisted of a vertical series of masonry blocks or slabs (three sequential sets of differently oriented pairs) among which were embedded two human skeletons, either dismembered or secondarily deposited, all in a midden-like matrix. The whole feature seems more like a cached offering than a burial done in reverence to those interred (Becker 1988; Carrelli 1990). It most likely related to the tomb, Burial XLII-6, a few meters to the south. If this inference is correct, it may also be significant that this fourfold set of pairs (three pairs of stones and one of skeletons) lay to the north of the burial, just as Group $8 \mathrm{~L}-10$ (with its multiple pairs) lies north of $8 \mathrm{~L}-12$, and the whole is north of the Principal Group (see Discussion).

Differences in architecture and settlement pattern were also evident between the two compounds. The ruined constructions of Group $8 \mathrm{~L}-12$ are a bit taller, but the plaza is smaller than in Group $8 \mathrm{~L}-10$, the visual effect being one of enclosed or private space in $8 \mathrm{~L}-12$ and open or public space in its northern neighbor. ${ }^{17}$ There is likewise a marked contrast in the abundance of small, ancillary structures, with at least 18 surrounding Group 8L-12 (not counting Group 8L-11, midway between the two larger compounds), and only one (or at most, three) near $8 \mathrm{~L}-10$. By analogy with similar features elsewhere (e.g., Ashmore 1981; Webster 1989; Willey and Leventhal 1979), these smaller structures are most likely domestic adjuncts, including kitchens, storehouses, and residences for servants. Other small groups are found in the general vicinity, but again the general distribution implies differences, in this case with respect to relations between the occupants of the principal groups and their attendants.

\section{DISCUSSION}

What was the relation between the two groups, and that between their occupants? To me, the organization of the evidence (the distribution of sculptural forms, of elaborate burials, and of mass and arrangement of architecture) implies marked differences between the two elite residences. Whatever the interpretation, the formal patterning is strongly consistent within each compound and contrastive between them. That of Group 8L-12 is more the overall form expected in a noble's compound, similar to (though smaller than) Patio A of Copán's Group 9N-8 (Webster 1989; Webster et al. 1986). That of Group $8 \mathrm{~L}-10$, however, appears to have been more oriented toward ritual activity, and toward an identity more abstract than personal. Artifacts recovered in excavation do suggest people lived in each compound, but that fact does not preclude the residents from having carried out other activities. I have proposed that the specific symbolic forms encountered in Group $8 \mathrm{~L}-10$ suggest the nature of these other activities, and that these involved affirmation of Copanec 
dynastic continuity. Given the late dates of some of the remains, these ongoing activities apparently constituted a symbolic negation of the actual royal collapse.

I further propose a specific relation between the two adjacent and imposing compounds of the North Group. These compounds form a pair on a north-south axis, conforming in part to the natural shape of the promontory they occupy. But the arrangement specifically pairs a more open compound on the north with a more enclosed one on the south, with suggested functional contrasts between the two. In these traits, the Copán North Group replicates the plan of the Principal Group (see Figure 4), as well as the schematized core layouts of Quiriguá, Tikal, and other centers, whose plans are argued elsewhere (Ashmore 1986, 1989a) to have been based on the site-planning principles described here. And just as one can see these civic centers as microcosms celebrating dynastic power, one can interpret the North Group layout as a whole as another deliberate allusion to royal transition, completion, and perpetuation. Where Group $8 \mathrm{~L}-10$ was associated with ritual, royalty, and perhaps resurrection of sovereigns, Group $8 \mathrm{~L}-12$ was linked to more worldly and, at least partially, to underworldly affairs (see below). In this scheme, it is the whole axis that is important, but one can nonetheless infer the symbolic associations for each terminus: In the Copán North Group, the north is associated with the heavens, and the south with the underworld. As in the most expansive expression of the template at Tikal, described earlier, it appears that the architecture occupying the northern position is itself a microcosmic arrangement (i.e., Twin Pyramid Group 3D-2 at Tikal and the North Group at Copán).

Perhaps there is another clue in the sculptured fragment of a shield found at Str. 8L-87. It is only a single fragment (CPN 15119; reconstructed in Figure 10), but shows clearly the cruller-eyed face of the Jaguar God of the Underworld (Miller 1988:178-181; Thompson 1971:134), or Xbalanque (Schele and Miller 1986:50, 272, 275). By analogy with the scribe sculptures on the Scribe's Palace, Str. 9N-82 (Fash 1986; Webster 1989; Webster et al. 1986), the shield hints at the identity of the principal occupant of Str. 8L-87 and presumably of its tomb. Perhaps a warrior is indicated (Miller 1988:178-179, Figure 26). At the same time, however, the shield could be an allusion to anticipated rebirth and exit from the underworld as described earlier (Edmonson 1971:142), and thereby to a role for the shield bearer in acts concerning rebirth or resurrection. This interpretation is separable from but also consistent with the view that the North Group overall and in intricately complex ways signified the combined themes of transition, rebirth, and perpetuation.

Finally, the original model may be reconsidered in light of data from the Copan North Group, as well as new interpretations from various sources. Evidence from several independent sources now points to an ancient Maya concept in which a north-south axis was defined, and to the equivalence of this axis, in some contexts, to a vertical dimension, to "above-below," or heavenunderworld. In this regard, I would reiterate the general observation that, whatever the symbolic significance, a strongly marked north-south axis unquestionably occurs in many Maya civic centers, from at least the Late Preclassic on (Ashmore 1986, 1987a, 1987b, 1987c, 1989a; Coggins 1967; Hammond 1987). Copán's Principal Group is one Late Classic instance of this pattern, and Mary Miller's (1988) analysis of the iconography of the southwardly located Copán Acropolis suggests strongly that south here did indeed stand for the underworld.

As already noted, east and west were recognized anciently, and east in particular is usually considered the primary position (e.g., Brotherston 1976; Coggins 1980; Marcus 1973; Roys 1967). Moreover, east and west may have been the only ones that consistently held directional and geographic significance. The references to east and west quadrants on Copán Stelae 13 and 19 were cited earlier, as well as the same site's east- and west-running causeways. Among modern Chorti Maya, Wisdom (1940) noted that roads leave town along cardinal directions, and that sometimes a road is named for its direction. However, the same author observed that only "east" and "west" have equivalents in the Chorti language. There are no Chorti words for "north" or "south" (Wisdom 1940:206, Note 6). The same "absence" occurs in Tzotzil Maya (Brotherston 1976; Vogt 1969:719). For this reason, Brotherston (1976:57; see also Coggins 1980:730) refers to north and south as "moments between" east and west.

Certainly there are references to xaman ("north") and nohol ("south") that appear to involve cardinal directions, examples including the famous texts of Copán Stela A and Seibal Stela 10 

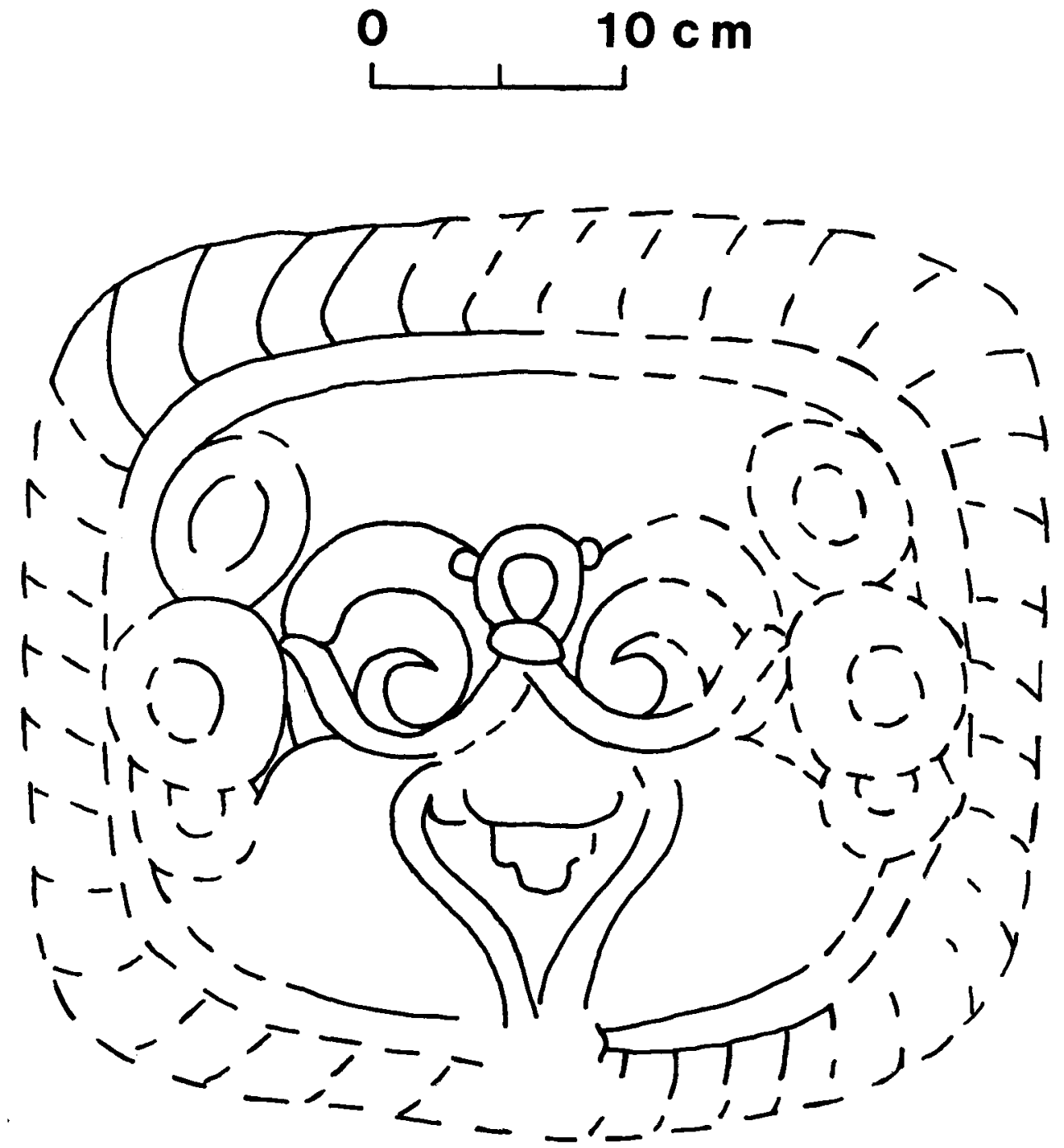

Figure 10. Fallen facade sculpture from Str. 8L-87, a tenoned shield with the face of the jaguar god of the underworld (CPN 15119; inking by C. Carrelli).

(Marcus 1973, 1976), the painted walls of Tomb 12, Río Azul (Adams 1986) already described, and the lexical definition of "north" for xaman in Yucatec (Closs 1988a, 1988b). But these instances could equally indicate the semantic complexity of the concepts xaman and nohol, and of the directional axis they define. Is it not possible that, as with Landa's "alphabet" proving to be a syllabary, the "north" and "south" translations provided by Yucatec informants were simply the closest approximations available in Spanish, rather than identically bounded concepts? The evidence seems rather to support Brotherston's (1976) implication that these two concepts, xaman and nohol, can prospectively connote a range of transitions between east and west-including above-below, heaven-underworld, and/or north-south.

With respect to the ancient Maya, the model of spatial conceptualization considered in this paper remains a hypothesis. So does current interpretation of the Copán North Group findings. For example, astronomical associations of Str. 8L-74's calendar-round date need further exploration (see Note 12), especially in light of others' independent comments on the particular importance of 
sun and Venus cycling and imagery at Copán (e.g., Aveni 1979; Baudez 1985, 1988; Coggins 1988b). Because of the incompleteness of the Str. $8 \mathrm{~L}-74$ text, the reference to "elder brother" necessarily remains cryptic, but ultimately it may turn out to be metaphorical rather than literal, with regard to 18 Rabbit as human or celestial sibling-or both. And certainly the aptness of the Popol Vuh "link," used provisionally herein, requires further critical review. Further excavations are warranted, to test patterns in the content of ritual deposits, as inferred above (e.g., by locating other deposits, such as within substructure masses) or to locate additional inscriptions (e.g., by clearing superstructures, in part to seek hieroglyphic benches like others known at Copán). Finally, archaeological exploration of the model's implications elsewhere, at Copán and beyond, is required to provide broader and independent evidence pertinent to these arguments.

Nevertheless, the Copán North Group research has begun a needed exploration and refinement of the original and derived hypotheses, systematically applying archaeological data along with those from epigraphy, linguistics, iconography, and ethnology, in a collaborative or conjunctive approach gaining renewed momentum in mesoamerican research (e.g., Diehl 1984; Fash and Sharer 1991; Fash and Stuart 1991; Fox 1987). There is a growing conviction (e.g., Hill 1990; Hodder 1990; Renfrew 1982) that material evidence concerning ancient idea systems may be more accessible archaeologically than previously held. As noted at the outset of this paper, analyses involving architectural and other spatial symbolism have already proven stimulating and fruitful in in a variety of ancient cultural settings, spanning a wide range of social complexity (e.g., Benson 1981; Fritz 1978, 1986; Hodder 1984; Taçon 1991). To be sure, this and other kinds of symbolic studies remain among the most challenging and interpretively ambiguous areas of archaeological research. Where contemporary historical records and continuities with the ethnographic present are available, however, the prospects for productive investigation are strong (Houston 1989). Such advantages are clearly present in Mesoamerica, and especially in the Maya area.

In a slightly different context, but no less pertinently, Olivier de Montmollin (1989:33, 34, 237) has recently challenged archaeologists to first dare asking interesting questions, and then develop the methods to address them (Binford 1962). Recent mesoamerican archaeology has yielded exciting insights in exploring multiple aspects of ancient idea systems (e.g., Culbert 1991; Fialko 1988; Flannery and Marcus 1976; Marcus 1989). Clearly the potentials are only beginning to be realized. The results of the Copán North Group Project are offered here as a step along a widening avenue of such investigation.

Acknowledgments. The Proyecto Arqueológico Copán de Cosmología (Copán North Group Project) was formed by contract with the Instituto Hondureño de Antropologia e Historia (Lic. Victor Cruz Reyes, former director, and Lic. José Maria Casco, director) and carried out its investigations with support from the National Geographic Society (Grants Nos. 3774-88, 4029-89) and Rutgers-The State University of New Jersey (Office of the Provost and the Graduate School).

Many individuals have contributed to development of the project and to exploration of the ideas on which it has focused. Editor Pru Rice has insisted there isn't page space in the journal to acknowledge all those I'd originally listed, but please know I thank you all nonetheless. And at the risk of severe editorial censure, I would like to thank the following-named individuals, for their particular help and consideration (in alphabetical order): Ricardo Agurcia F., Oscar Cruz M., Victor Cruz R., Barbara and William Fash, AnnCorinne Freter, Rudy Larios V., Prudence Rice, William Ringle, Robert Sharer, Rebecca Storey, David Stuart, George Stuart, Vito Véliz R., David Webster, and especially the other members of the North Group project-Christine Carrelli, Matthew Gajewski, Sharon Horan, Alessandro Pezzati, Arturo Sandoval, and Susan Swiat. No one but me is responsible for errors or misjudgments.

\section{REFERENCES CITED}

Adams, R. E. W

1986 Río Azul. National Geographic Magazine 169:420-451.

Ashmore, W.

1980 Discovering Early Classic Quiriguá. Expedition 23(1):33-44.

1985 Excavaciones en el Centro Selecto de Gualjoquito, Santa Bárbara, 1983-1985. Paper presented at the Tercer Seminario de Arqueologia Hondureña, Tela, Honduras. 
1986 Petén Cosmology in the Maya Southeast: An Analysis of Architecture and Settlement Patterns at Classic Quiriguá. In The Southeast Maya Periphery, edited by P. A. Urban and E. M. Schortman, pp. 3549. University of Texas Press, Austin.

1987a Deciphering Maya Site Plans. Paper presented at the Fifth Annual Maya Weekend, University Museum Centennial Celebration, University of Pennsylvania, Philadelphia. Pennsylvania.

1987b La dirección norte en la arquitectura precolombina del sureste de Mesoamérica. Paper presented at the Cuarto Seminario de Arqueología Hondureña, La Ceiba, Honduras.

1987c Cobble Crossroads: Gualjoquito Architecture and External Elite Ties. In Interaction on the Southeast Mesoamerican Periphery: Prehistoric and Historic Honduras and El Salvador, edited by E. J. Robinson, pp. 28-48. BAR International Series 327. British Archaeological Reports, Oxford.

1989a Construction and Cosmology: Politics and Ideology in Lowland Maya Settlement Patterns. In Word and Image in Maya Culture: Explorations in Language, Writing, and Representation, edited by W. F. Hanks and D. S. Rice, pp. 272-286. University of Utah Press, Salt Lake City.

1989b El Proyecto Arqueológico Copán de Cosmología: Conceptos de direccionalidad entre los antiguos mayas. Paper presented at the Quinto Seminario de Arqueología Hondureña, Copán Ruinas, Honduras.

Ashmore, W. (compiler)

1988 Proyecto Arqueológico Copán de Cosmología: Temporada de 1988, informe preliminar. Submitted to the Instituto Hondureño de Antropología e Historia, Copán Ruinas and Tegucigalpa, and National Geographic Society, Washington, D.C.

1989 Proyecto Arqueológico Copán de Cosmologia: Temporada de 1989, informe preliminar. Submitted to the Instituto Hondureño de Antropologia e Historia, Copán Ruinas and Tegucigalpa, and National Geographic Society, Washington, D.C.

Ashmore, W. (editor)

1981 Lowland Maya Settlement Patterns. University of New Mexico Press, Albuquerque.

Aveni, A. F.

1979 Venus and the Maya. American Scientist 67:274-285.

1980 Skywatchers of Ancient Mexico. University of Texas Press, Austin.

Aveni, A. F., and H. Hartung

1978 Some Suggestions about the Arrangement of Buildings at Palenque. In Tercera Mesa Redonda de Palenque, vol. IV, edited by M. G. Robertson and D. C. Jeffers, pp. 173-177. Pre-Columbian Art Research, Monterey.

1986 Maya City Planning and the Calendar. Transactions of the American Philosophical Society 76(7). Philadelphia.

Bardawil, L. W.

1976 The Principal Bird Deity in Maya Art-An Iconographic Study of Form and Meaning. In The Art, Iconography and Dynastic History of Palenque, part III, edited by M. G. Robertson, pp. 195-209. PreColumbian Art Research, The Robert Louis Stevenson School, Pebble Beach.

Baudez, C. F.

1985 The Sun Kings at Copán and Quiriguá. In Fifth Palenque Round Table, 1983, edited by M. G. Robertson and V. M. Fields, pp. 29-37. The Pre-Columbian Art Research Institute, San Francisco.

1988 Solar Cycle and Dynastic Succession in the Southeast Maya Zone. In The Southeast Classic Maya Zone, edited by E. H. Boone and G. R. Willey, pp. 125-148. Dumbarton Oaks, Washington, D.C.

1991 The Cross Pattern at Copán, Honduras: Forms, Rituals, and Meanings. In Sixth Palenque Round Table, 1986 , edited by M. G. Robertson and V. M. Fields, pp. 81-88. University of Oklahoma Press, Norman.

Baudez, C. F. (editor)

1983 Introducción a la arqueología de Copán, Honduras. 3 vols. Secretaria del Estado en el Despacho de Cultura y Turismo, Tegucigalpa.

Becker, M. J.

1988 Caches as Burials, Burials as Caches: The Meaning of Ritual Deposits Among the Classic Period Lowland Maya. In Recent Studies in Pre-Columbian Archaeology, edited by N. J. Saunders and O. de Montmollin, pp. 117-142. BAR International Series 421. British Archaeological Reports, Oxford.

Benson, E. P. (editor)

1981 Mesoamerican Sites and World-Views. Dumbarton Oaks, Washington, D. C.

Binford, L. R.

1962 Archaeology as Anthropology. American Antiquity 28:217-225.

Blier, S. P.

1987 The Anatomy of Architecture: Ontology and Metaphor in Batammaliba Architectural Expression. Cambridge University Press, Cambridge.

Bourdieu, $\mathbf{P}$.

1973 The Berber House. In Rules and Meanings, edited by M. Douglas, pp. 98-110. Penguin, Harmondsworth, England.

1977 Outline of a Theory of Practice. Translated by R. Nice. Cambridge University Press, Cambridge.

Bricker, V. R.

1983 Directional Glyphs in Maya Inscriptions and Codices. American Antiquity 48:347-353.

1988 A Phonetic Glyph for Zenith: Reply to Closs. American Antiquity 53:394-400. 
Brotherston, $\mathbf{G}$.

1976 Mesoamerican Description of Space II: Signs for Direction. Ibero-Amerikanisches Archiv N.F. Jg 2 , H. 1:39-62.

Bullard, M. R., and R. J. Sharer

1991 Ceramics of Quiriguá. Quiriguá Reports, vol. V. Ms. on file, American Section, The University Museum, University of Pennsylvania, Philadelphia.

Carlsen, R. S., and M. Prechtel

1991 The Flowering of the Dead: An Interpretation of Highland Maya Culture. Man 26:23-42.

Carlson, J. B.

1980 On Classic Maya Monumental Recorded History. In Third Palenque Round Table, 1978, part 2, vol. 5, edited by M. G. Robertson, pp. 199-203. University of Texas Press, Austin.

Carr, R. F., and W. E. Hazard

1961 Map of the Ruins of Tikal, El Petén, Guatemala. Tikal Reports No. 11. Museum Monograph No. 21. The University Museum, University of Pennsylvania, Philadelphia.

Carrelli, C. W.

1990 Mortuary Practices in Groups 8L-10 and 8L-12, Copän, Honduras. Unpublished B.A. honors thesis, Department of Anthropology, Rutgers-The State University of New Jersey, New Brunswick.

Clancy, F. S.

1988 The Compositions and Contexts of the Classic Stelae at Copán and Quiriguá. In The Southeast Classic Maya Zone, edited by E. H. Boone and G. R. Willey, pp. 195-221. Dumbarton Oaks, Washington, D.C.

Closs, M. P.

1979 Venus in the Maya World: Glyphs, Gods and Associated Astronomical Phenomena. In Tercera Mesa Redonda de Palenque, vol. IV, edited by M. G. Robertson and D. C. Jeffers, pp. 147-165. Pre-Columbian Art Research, Monterey.

1988a A Phonetic Version of the Maya Glyph for North. American Antiquity 53:386-393.

1988b Response to Coggins and Bricker. American Antiquity 53:402-411.

Coe, M. D.

1965 A Model of Ancient Community Structure in the Maya Lowlands. Southwestern Journal of Anthropology 21:97-114.

1988 Ideology of the Maya Tomb. In Maya Iconography, edited E. P. Benson and G. G. Griffin, pp. 222235. Princeton University Press, Princeton.

Coe, W. R., and R. Larios V.

1988 Tikal, a Handbook of the Ancient Maya Ruins. 2nd ed. The University Museum, University of Pennsylvania, Philadelphia, and Asociación Tikal, Guatemala.

Coggins, C. C.

1967 Palaces and the Planning of Ceremonial Centers in the Maya Lowlands. Ms. on file, Tozzer Library, Peabody Museum, Harvard University, Cambridge.

1980 The Shape of Time: Some Political Implications of a Four-Part Figure. American Antiquity 45:727739.

1986 Reply to: A Phonetic Version of the Maya Glyph for North. Ms. in possession of author.

1988a Reply to: A Phonetic Version of the Maya Glyph for North. American Antiquity 53:401.

$1988 \mathrm{~b}$ On the Historical Significance of Decorated Ceramics at Copán and Quiriguá and Related Classic Maya Sites. In The Southeast Classic Maya Zone, edited by E. H. Boone and G. R. Willey, pp. 95-123. Dumbarton Oaks, Washington, D.C.

1988c Classic Maya Metaphors of Death and Life. Res 16:64-84.

Culbert, T. P. (editor)

1991 Classic Maya Political History: Hieroglyphic and Archaeological Evidence. Cambridge University Press, Cambridge.

de Montmollin, $\mathbf{O}$.

1988 Tenam Rosario-A Political Microcosm. American Antiquity 53:351-370.

1989 The Archaeology of Political Structure: Settlement Analysis in a Classic Maya Polity. Cambridge University Press, Cambridge.

Diehl, R. A.

1984 Current Directions and Perspectives in Mesoamerican Cognitive Archaeology. Latin American Research Review 19(2):171-181.

Donley, L. W.

1982 House Power: Swahili Space and Symbolic Markers. In Symbolic and Structural Archaeology, edited by I. Hodder, pp. 63-73. Cambridge University Press, Cambridge.

Douglas, $\mathbf{M}$.

1972 Symbolic Orders in the Use of Domestic Space. In Man, Settlement and Urbanism, edited by P. J. Ucko, R. Tringham, and G. W. Dimbleby, pp. 513-521. Duckworth, London.

Dütting, D.

1985a Lunar Periods and the Quest for Rebirth in the Mayan Hieroglyphic Inscriptions. Estudios de Cultura Maya 16:113-147. 
1985b On the Astronomical Background of Mayan Historical Events. In Fifth Palenque Round Table, 1983, edited by M. G. Robertson and V. M. Fields, pp. 261-274. The Pre-Columbian Art Research Institute, San Francisco.

Edmonson, M. S.

1971 The Book of Counsel: The Popol Vuh of the Quiché Maya. Publication No. 35. Middle American Research Institute, Tulane University, New Orleans.

Fash, W. L., Jr.

1983a Classic Maya State Formation: A Case Study and Its Implications. Ph.D. dissertation, Harvard University. University Microfilms, Ann Arbor.

1983b Deducing Social Organization from Classic Maya Settlement Patterns: A Case Study from the Copán Valley. In Civilization in the Ancient Americas: Essays in Honor of Gordon $R$. Willey, edited by $\mathbf{R}$. M. Leventhal and A. L. Kolata, pp. 261-288. University of New Mexico Press, Albuquerque, and Peabody Museum, Harvard University, Cambridge.

1986 La fachada esculpida de la estructura 9N-82: Composición, forma e iconografia. In Excavaciones en el ârea urbana de Copán, tomo I, edited by W. T. Sanders, pp. 319-382. Secretaria de Cultura y Turismo, Instituto Hondureño de Antropología e Historia, Tegucigalpa.

1988 A New Look at Maya Statecraft from Copán, Honduras. Antiquity 62:157-169.

1989 The Sculptural Façade of Structure 9N-82: Content, Form, and Significance. In The House of the Bacabs, Copán, Honduras, edited by D. L. Webster, pp. 41-72. Dumbarton Oaks, Washington, D.C.

Fash, W. L., Jr., and B. W. Fash

1990 Scribes, Warriors, and Kings: The Lives of the Copán Maya. Archaeology 43(3):26-35.

Fash, W. L., Jr., and K. Z. Long

1983 Mapa arqueológico del valle de Copán. In Introducción a la arqueología de Copán, Honduras, tomo III, edited by C. F. Baudez. Secretaria del Estado en el Despacho de Cultura y Turismo, Tegucigalpa.

Fash, W. L., Jr., and R. J. Sharer

1991 Sociopolitical Developments and Methodological Issues at Copán, Honduras: A Conjunctive Perspective. Latin American Antiquity 2:166-187.

Fash, W. L., Jr., and D. S. Stuart

1991 Dynastic History and Cultural Evolution at Copán, Honduras. In Classic Maya Political History: Hieroglyphic and Archaeological Evidence, edited by T. P. Culbert, pp. 147-179. Cambridge University Press, Cambridge.

Fernandez, J. W.

1977 Fang Architectonics. Institute for the Study of Human Issues, Philadelphia.

Fialko, V.

1988 Mundo perdido, Tikal: Un ejemplo de complejos de conmemoración astronómica. Mayab 4:13-21.

Flannery, K. V., and J. Marcus

1976 Formative Oaxaca and the Zapotec Cosmos. American Scientist 64:374-383.

Fox, J. W.

1987 Maya Postclassic State Formation. Cambridge University Press, Cambridge.

1991 Factionalism Among the Postclassic Quiché Maya: The Calendar for Competition and Cooperation. In Factional Competition and Political Development in the New World, edited by E. Brumfiel and J. W. Fox. Cambridge University Press, Cambridge, in press.

Freidel, D. A.

1979 Culture Areas and Interaction Spheres: Contrasting Approaches to the Emergence of Civilization in the Maya Lowlands. American Antiquity 44:36-54.

1981 Civilization as a State of Mind: The Cultural Evolution of the Lowland Maya. In The Transition to Statehood in the New World, edited by G. D. Jones and R. R. Kautz, pp. 188-227. Cambridge University Press, Cambridge.

1986 Introduction. In Archaeology at Cerros, Belize, Central America, edited by R. A. Robertson and D. A. Freidel, pp. xiii-xxi. Southern Methodist University Press, Dallas.

Freidel, D. A., and L. Schele

1988a Symbol and Power: A History of the Lowland Maya Cosmogram. In Maya Iconography, edited by E. P. Benson and G. G. Griffin, pp. 44-93. Princeton University Press, Princeton.

1988b Kingship in the Late Preclassic Maya Lowlands: The Instruments and Places of Ritual Power. American Anthropologist 90:547-567.

Freidel, D. A., C. Suhler, and R. Krochock

1990 Yaxuna Archaeological Survey: A Report of the 1989 Field Season and Final Report on Phase One. Ms. on file, Department of Anthropology, Southern Methodist University, Dallas.

Freidel, D. A., M. Masucci, S. Jaeger, and R. A. Robertson

1991 The Bearer, the Burden, and the Burnt: The Stacking Principle in the Iconography of the Late Preclassic Maya Lowlands. In Sixth Palenque Round Table, 1986, edited by M. G. Robertson and V. M. Fields, pp. 175-183. University of Oklahoma Press, Norman.

Fritz, J. M.

1978 Paleopsychology Today: Ideational Systems and Human Adaptation in Prehistory. In Social Arche- 
ology: Beyond Subsistence and Dating, edited by C. L. Redman, M. J. Berman, E. V. Curtin, W. T. Langhorne, Jr., N. M. Versaggi, and J. C. Wanser, pp. 37-59. Academic Press, New York.

1986 Vijayanagara: Authority and Meaning of a South Indian Imperial Capital. American Anthropologist 88:44-55.

Gajewski, M. Z.

1988 Chipped Stone. In Proyecto Arqueológico Copán de Cosmología: Temporada de 1988, informe preliminar, compiled by W. Ashmore, pp. 10-11. Submitted to the Instituto Hondureño de Antropología e Historia, Copán Ruinas and Tegucigalpa, and National Geographic Society, Washington, D.C.

1989 Chipped and Ground Stone. In Proyecto Arqueológico Copán de Cosmología: Temporada de 1989, informe preliminar, compiled by W. Ashmore, pp. 8-9. Submitted to the Instituto Hondureño de Antropología e Historia, Copán Ruinas and Tegucigalpa, and National Geographic Society, Washington, D.C.

Gillespie, S. D.

1985 Ballgames and Boundaries. Paper presented at International Symposium on the Mesoamerican Ballgame and Ballcourts, Tucson.

1989 The Aztec Kings: The Construction of Rulership in Mexican History. University of Arizona Press, Tucson.

Gordon, G. B.

1896 Prehistoric Ruins of Copán, Honduras. Memoirs of the Peabody Museum of Archaeology and Ethnology Vol. 1, No. 1. Peabody Museum, Harvard University, Cambridge.

Gossen, G. H.

1974 Chamulas in the World of the Sun. Harvard University Press, Cambridge.

Grube, N., and L. Schele

1987 U Cit-Tok, the Last King of Copán. Copán Notes No. 21. Instituto Hondureño de Antropología e Historia and the Copán Mosaics Project, Austin.

1988 A Quadrant Tree at Copán. Copán Notes No. 43. Instituto Hondureño de Antropología e Historia and the Copán Mosaics Project, Austin.

Guillemin, G. F.

1968 Development and Function of the Tikal Ceremonial Center. Ethnos 33:1-35.

Hammond, $\mathbf{N}$.

1987 The Sun Also Rises: Iconographic Syntax of the Pomona Flare. Research Reports on Ancient Maya Writing No. 7. Center for Maya Research, Washington, D.C.

Hill, J. N.

1990 Is Prehistoric Cognition Scientifically Cognizable? Paper presented at the Conference on Processual and Postprocessual Approaches in Archaeology, Cambridge University, Cambridge.

Hodder, I.

1984 Burials, Houses, Women and Men in the European Neolithic. In Ideology, Power and Prehistory, edited by D. Miller and C. Tilley, pp. 51-68. Cambridge University Press, Cambridge.

1987 The Contextual Analysis of Symbolic Meanings. In The Archaeology of Contextual Meanings, edited by I. Hodder, pp. 1-10. Cambridge University Press, Cambridge.

1990 The Domestication of Europe: Structure and Contingency in Neolithic Societies. Basil Blackwell, Oxford. Horan, S. A.

1988 Sculpture. In Proyecto Arqueológico Copán de Cosmologia: Temporada de 1988, informe preliminar, compiled by W. Ashmore, pp. 11-14. Submitted to the Instituto Hondureño de Antropología e Historia, Copán Ruinas and Tegucigalpa, and National Geographic Society, Washington, D.C.

1989 Sculpture. In Proyecto Arqueológico Copán de Cosmologia: Temporada de 1989, informe preliminar, compiled by W. Ashmore, pp. 9-10. Submitted to the Instituto Hondureño de Antropología e Historia, Copán Ruinas y Tegucigalpa, and National Geographic Society, Washington, D.C.

Houston, S. D.

1989 Archaeology and Maya Writing. Journal of World Prehistory 3:1-32.

Houston, S. D., and P. Mathews

1985 The Dynastic Sequence of Dos Pilas, Guatemala. Monograph No. 1. Pre-Columbian Art Research Institute, San Francisco.

Jones, C.

1969 The Twin-Pyramid Group Pattern: A Classic Maya Architectural Assemblage at Tikal, Guatemala. Ph.D. dissertation, University of Pennsylvania. University Microfilms, Ann Arbor.

Justeson, J. S., W. M. Norman, and N. Hammond

1988 The Pomona Flare: A Preclassic Hieroglyphic Text. In Maya Iconography, edited by E. P. Benson and G. G. Griffin, pp. 94-151. Princeton University Press, Princeton.

Kelley, D. H.

1962 Glyphic Evidence for a Dynastic Sequence at Quiriguá, Guatemala. American Antiquity 27:323-335.

Kelley, J. H., and M. P. Hanen

1988 Archaeology and the Methodology of Science. University of New Mexico Press, Albuquerque.

Kuper, $\mathbf{H}$.

1972 The Language of Sites in the Politics of Space. American Anthropologist 74:411-425. 
Laporte, J. P., and V. Fialko C.

1990 New Perspectives on Old Problems: Dynastic References for the Early Classic at Tikal. In Vision and Revision in Maya Studies, edited by F. S. Clancy and P. D. Harrison, pp. 33-66. University of New Mexico Press, Albuquerque.

Lawrence, D. L., and S. M. Low

1990 The Built Environment and Spatial Form. Annual Review of Anthropology 19:453-505.

Leach, E. R.

1983 The Gatekeepers of Heaven: Anthropological Aspects of Grandiose Architecture. Journal of Anthropological Research 29: 243-264.

Longyear, J. M. III

1952 Copán Ceramics: A Study of Southeastern Maya Pottery. Publication No. 597. Carnegie Institution of Washington, Washington, D.C.

Lounsbury, F. G.

1976 A Rationale for the Initial Date of the Temple of the Cross at Palenque. In The Art, Iconography and Dynastic History of Palenque, part III, edited by M. G. Robertson, pp. 211-224. Pre-Columbian Art Research, The Robert Louis Stevenson School, Pebble Beach.

Marcus, J.

1973 Territorial Organization of the Lowland Classic Maya. Science 180:911-916.

1976 Emblem and State in the Maya Lowlands: An Epigraphic Approach to Territorial Organization. Dumbarton Oaks, Washington, D.C.

1989 Zapotec Chiefdoms and the Nature of Formative Religions. In Regional Perspectives on the Olmec, edited by R. J. Sharer and D. C. Grove, pp. 148-197. Cambridge University Press, Cambridge.

Matheny, R. T.

1987 Early States in the Maya Lowlands During the Late Preclassic Period: Edzna and El Mirador. In CityStates of the Maya: Art and Architecture, edited by E. P. Benson, pp. 1-44. Rocky Mountain Institute for Pre-Columbian Studies, Denver.

Miller, M. E.

1985 Tikal, Guatemala: A Rationale for the Placement of the Funerary Pyramids. Expedition 27(3):6-15.

1988 The Meaning and Function of the Main Acropolis, Copán. In The Southeast Classic Maya Zone, edited by E. H. Boone and G. R. Willey, pp. 149-194. Dumbarton Oaks, Washington, D.C.

Morley, S. G.

1920 The Inscriptions at Copán. Publication No. 219. Carnegie Institution of Washington, Washington, D.C.

Nabakov, P., and R. Easton

1989 Native American Architecture. Oxford University Press, Oxford.

Niles, S. A.

1987 Callachaca: Style and Status in an Inca Community. University of Iowa Press, Iowa City.

Proskouriakoff, T.

1968 The Jog and the Jaguar Signs in Maya Writing. American Antiquity 33:247-251.

1973 The Hand-Grasping-Fish and Associated Glyphs on Classic Maya Monuments. In Mesoamerican Writing Systems, edited by E. P. Benson, pp. 165-178. Dumbarton Oaks, Washington, D.C.

Renfrew, C.

1982 Towards an Archaeology of Mind. Inaugural Lecture Delivered Before the University of Cambridge. Cambridge University Press, Cambridge.

Riese, $\mathbf{B}$.

1984 Hel Hieroglyphs. In Phoneticism in Mayan Hieroglyphic Writing, edited by J. S. Justeson and L. Campbell, pp. 263-286. Publication No. 9. Institute for Mesoamerican Studies, State University of New York, Albany.

1986 Late Classic Relationship between Copán and Quiriguá: Some Epigraphic Evidence. In The Southeast Maya Periphery, edited by P. A. Urban and E. M. Schortman, pp. 94-101. University of Texas Press, Austin.

Roys, R. L. (translator and editor)

1967 The Book of Chilam Balam of Chumayel. University of Oklahoma Press, Norman.

Ruppert, K. J.

1977 A Special Assemblage of Maya Structures. In The Maya and Their Neighbors, edited by C. L. Hay, R. L. Linton, S. K. Lothrop, H. L. Shapiro, and G. C. Vaillant, pp. 222-231. Reprinted. Dover, New York. Originally published 1940 . Appleton-Century, New York.

Sabloff, J. A.

1975 Excavations at Seibal: Ceramics. Memoirs of the Peabody Museum of Archaeology and Ethnology Vol. 13, No. 2. Harvard University, Cambridge.

Sanders, W. T. (editor)

1986 Excavaciones en el área urbana de Copân, tomo I. Secretaria de Cultura y Turismo, Instituto Hondureño de Antropologia e Historia, Tegucigalpa.

1990 Excavaciones en el área urbana de Copán, tomo II. Secretaria de Cultura y Turismo, Instituto Hondureño de Antropología e Historia, Tegucigalpa. 
Schele, L.

1977 Palenque: The House of the Dying Sun. In Native American Astronomy, edited by A. F. Aveni, pp. 42-56. University of Texas Press, Austin.

1984 Human Sacrifice among the Classic Maya. In Ritual Human Sacrifice in Mesoamerica, edited by E. P. Benson and E. H. Boone, pp. 6-48. Dumbarton Oaks, Washington, D.C.

1991 An Epigraphic History of the Western Maya Region. In Classic Maya Political History: Hieroglyphic and Archaeological Evidence, edited by T. P. Culbert, pp. 72-101. Cambridge University Press, Cambridge.

Schele, L., and D. A. Freidel

1990 A Forest of Kings: The Untold Story of the Ancient Maya. William Morrow, New York.

Schele, L., and N. Grube

1988 Stela 13 and the East Quadrant of Copán. Copán Notes No. 44. Instituto Hondureño de Antropología e Historia and the Copán Mosaics Project, Austin.

Schele, L., and J. H. Miller

1983 The Mirror, the Rabbit, and the Bundle: "Accession" Expressions from the Classic Maya Inscriptions. Studies in Pre-Columbian Art and Archaeology No. 25. Dumbarton Oaks, Washington, D.C.

Schele, L., and M. E. Miller

1986 The Blood of Kings: Dynasty and Ritual in Maya Art. Kimball Art Museum, Fort Worth.

Schele, L., N. Grube, and D. Stuart

1989 The Date of Dedication of Ballcourt III at Copán. Copán Notes No. 59. Instituto Hondureño de Antropología e Historia and the Copán Mosaics Project, Austin.

Sharer, R. J.

1978 Archaeology and History at Quiriguá, Guatemala. Journal of Field Archaeology 5:51-70.

Steinhardt, N. S.

1986 Why Were Chang'an and Beijing So Different? Journal of the Society of Architectural Historians 43: $339-357$.

Stone, A.

1985 Variety and Transformation in the Cosmic Monster Theme at Quiriguá. In Fifth Palenque Round Table, 1983, edited by M. G. Robertson and V. M. Fields, pp. 39-48. The Pre-Columbian Art Research Institute, San Francisco.

Stromsvik, G.

1941 Substela Caches and Stela Foundations at Copán and Quiriguá. Contributions to American Anthropology and History 7(37):63-96. Publication No. 528. Carnegie Institution of Washington, Washington, D.C.

Stuart, D.

1987 New Data on the Copán Dynasty. Paper presented at the Cuarto Seminario de Arqueologia Hondureña, La Ceiba, Honduras.

1989a Comments on the Temple 22 Inscription. Copán Notes No. 63. Instituto Hondureño de Antropología e Historia and the Copan Mosaics Project, Austin.

1989b The Dynastic History of Copán. Paper presented at the 88th Annual Meeting of the American Anthropological Association, Washington, D. C.

Stuart, D., N. Grube, L. Schele, and F. Lounsbury

1989 Stela 63, a New Monument from Copán. Copán Notes No. 56. Instituto Hondureño de Antropología e Historia and the Copán Mosaics Project, Austin.

Stuart, D., L. Schele, and N. Grube

1989 A Mention of 18 Rabbit on the Temple 11 Reviewing Stand. Copán Notes No. 62. Instituto Hondureño de Antropologia e Historia and the Copán Mosaics Project, Austin.

Swiat, S. M.

1990 Is North "Up"? Discussing Directionality Among the Ancient Maya. Unpublished Master's thesis, Department of Anthropology, Rutgers-The State University of New Jersey, New Brunswick.

Taçon, P. S. C.

1991 The Power of Stone: Symbolic Aspects of Stone Use and Tool Development in Western Arnhem Land, Australia. Antiquity 65:192-207.

Tate, $C$.

1985 Summer Solstice Ceremonies Performed by Bird Jaguar III of Yaxchilán, Chiapas, México. Estudios de Cultura Maya 16:85-112.

Taube, K. A.

1987 A Representation of the Principal Bird Deity in the Paris Codex. Research Reports on Ancient Maya Writing No. 6. Center for Maya Research, Washington, D.C.

Taylor, T. F.

1987 Archaeology and the Norwegian Cultural Landscape. Current Anthropology 28:230-233.

Tedlock, D. E.

1985 Popol Vuh: The Mayan Book of the Dawn of Life. Simon and Schuster, New York.

Thompson, J. E. S.

1962 A Catalog of Maya Hieroglyphs. University of Oklahoma Press, Norman.

1971 Maya Hieroglyphic Writing. 3rd ed. University of Oklahoma Press, Norman. 
Tuan, Y. F.

1977 Space and Place: The Perspective of Experience. University of Minnesota Press, Minneapolis.

Turner, $\mathrm{V}$.

1974 Dramas, Fields, and Metaphors: Symbolic Action in Human Society. Cornell University Press, Ithaca.

Viel, R.

1983 Evolución de la cerámica en Copán: Resultados preliminares. In Introducción a la arqueología de Copán, Honduras, tomo I, edited by C. F. Baudez, pp. 471-549. Secretaria del Estado en el Despacho de Cultura y Turismo, Tegucigalpa.

Vogt, E. Z

1969 Zinacantan: A Maya Community in the Highlands of Chiapas. Belknap Press, Cambridge.

Webster, D. L. (editor)

1989 The House of the Bacabs, Copán, Honduras. Studies in Pre-Columbian Art and Archaeology No. 29. Dumbarton Oaks, Washington, D.C.

Webster, D. L., and A. C. Freter

1990a Settlement History and the Classic Collapse at Copán: A Redefined Chronological Perspective. Latin American Antiquity 1:66-85.

1990b The Demography of Late Classic Copán. In Precolumbian Population History in the Maya Lowlands, edited by T. P. Culbert and D. S. Rice, pp. 37-61. University of New Mexico Press, Albuquerque.

Webster, D. L., and N. Gonlin

1988 Household Remains of the Humblest Maya. Journal of Field Archaeology 15:169-190.

Webster, D. L., W. L. Fash, and E. M. Abrams

1986 Excavaciones en el conjunto 9N-8, Patio A (Operación VIII). In Excavaciones en el área urbana de Copán, tomo I, edited by W. T. Sanders, pp. 155-317. Secretaria de Cultura y Turismo, Instituto Hondureño de Antropologia e Historia, Tegucigalpa.

Willey, G. R., and R. M. Leventhal

1979 A Preliminary Report on Prehistoric Maya Settlement in the Copán Valley. In Maya Archaeology and Ethnohistory, edited by N. Hammond and G. R. Willey, pp. 75-102. University of Texas Press, Austin.

Willey, G. R., R. M. Leventhal, and W. L. Fash, Jr.

1978 Maya Settlement in the Copán Valley. Archaeology 31(4):32-43.

Wisdom, C.

1940 The Chorti Indians of Guatemala. University of Chicago Press, Chicago.

Wren, L. H.

1989 Composition and Content in Maya Sculpture: A Study of Ballgame Scenes at Chichén Itzá, Yucatán, México. In Ethnographic Encounters in Southern Mesoamerica: Essays in Honor of Evon Zartman Vogt, $J r$, edited by V. R. Bricker and G. H. Gossen, pp. 287-301. Studies in Culture and Society No. 3. Institute for Mesoamerican Studies, State University of New York, Albany.

\section{NOTES}

${ }^{1}$ Michael Closs (1988a, 1988b) has disagreed with the directional associations attributed here, and his arguments are considered later in the paper.

${ }^{2}$ Mary Miller (1985) has offered a different rationale for placement of Tikal's Great Temples. Her view and that presented here need not be seen as incompatible.

3 'Claude Baudez (1991) has independently described references to cruciform plans of varying scales at Copán; his conceptualization differs slightly from that considered here, but the two views are not mutually contradictory.

${ }^{4}$ See also Horan $(1988,1989)$. In connection with the foregoing it is also worth mentioning that a midden north of Str. $8 \mathrm{~L}-78$ yielded a burned eccentric (Cat. No. XLII/13/6-2), a type of lithic artifact associated with sacrifice and not generally found in domestic contexts.

${ }^{5}$ Not all epigraphers agree on reading the name of this ruler. Thompson (1962:354) interpreted the creature represented in the T757 glyph as a combination "jaguar" and "dog"; hence the word "jog." Kelley (1962:Figure 2) identified the XVIII. Jog collocation as the name of a ruler at Copán, so this reading has historical precedence (Marcus 1976; Proskouriakoff 1968, 1973). It remains the preferred reading for some, who read T757 as "pocket gopher" (e.g., Fash 1988; William Ringle, personal communication 1991). Other epigraphers, however, have argued on semantic grounds that T757 does portray a rabbit, and therefore read the ruler's name as 18 Rabbit (Riese 1986:100; Schele and Miller 1983:28, 49-50).

- The text is grammatically incomplete, and may well have begun on another side of the building, probably the north. In this regard, it is especially important to note the degree of clearing involved in project excavations. In 1988, excavations cleared the entire length of the plaza along the west side of the platform supporting Str. 8L-74 (Ashmore, comp. 1988). East-west extent of excavation varied with location, extending westward from $1.6 \mathrm{~m}$ to $4.4 \mathrm{~m}$ from the platform, and eastward, but never higher than the riser face of the third platform step. The terms of the permit precluded more extensive clearing of the mound itself, but limited tests were undertaken in 1989 along the other three sides of Str. 8L-74. Few other sculpture fragments were recovered, and no further glyph medallions (Ashmore, comp. 1989).

Two other medallions are known, portraits of the sun and moon deities (CPN 744 and 1007), but the precise 
relation of these sculptures to the facade text is unknown. The two were identified from collections of miscellaneous, minimally documented sculpture assembled from various parts of the valley in previous years (e.g., from local landowners). Since the specific "tenoned-medallion" form of the two pieces has otherwise been encountered only in the text elements of the Str. 8L-74 facade, the ascribed provenience seems strongly probable, though details on position cannot be determined.

${ }^{7}$ Subplaza tests were conducted on the south side of Group 8L-10, but the apparent lack of ritual deposits could still be a result of sampling insufficiency. Ritual deposits were also sought exterior along the south side of Str. 8L-78, but none were found.

${ }^{8}$ The occurrence of a hel glyph on Str. 8L-74 may be coincidental here. As William Ringle (personal communication 1991) points out, most occurrences in comparable contexts refer "either to a distance number [linking dates] or to the Nth ruler" in the local dynastic sequence. The text remains too fragmentary to say more.

${ }^{9}$ In many interpretations (e.g., Freidel and Schele 1988a:83), it is Xbalanque who becomes the sun and Hunahpu who becomes Venus, rather than the reverse. Alternatively (or later?), the pair becomes the sun and moon (Baudez 1985:35; Fox 1991; Schele and Miller 1986:245, 309; Tedlock 1985:46). Hunahpu may be the young (morning) sun, while Xbalanque is the dying (afternoon) aspect (Fox 1991). Venus and the full moon are sometimes seen as equivalent (Tedlock 1985:369), or Venus becomes the sun (Tedlock 1985:342). Sometimes these twins' father and uncle (themselves twins) are said to have become Venus as morning and/or evening star (e.g., Closs 1979:153; Tedlock 1985:353). The interpretive situation is obviously far from neatly resolved, but perhaps the aboriginal interpretations were more fluid than twentieth-century western analysts would prefer (e.g., Schele and Miller 1986:306, Note 3; Tedlock 1985:296-297). Nevertheless, in all views, the three celestial entities cited are seen as closely interrelated (e.g., Edmonson 1971:170; Tedlock 1985:46, 369; Thompson 1971) and, together, as central players in the primordial cosmic drama of both generation and perpetuation of the universe as the sixteenth-century Quiché Maya knew it. And all are specifically involved in processes of birth and/or rebirth. Whether or not the Popol Vuh is an appropriate analogue for interpreting Classic symbolism is a serious and likewise unresolved issue, though various lines of research have suggested the document is productive as a working analogue (e.g., Carlsen and Prechtel 1991; Fash and Fash 1990; Schele and Miller 1986).

${ }^{10}$ See also Schele and Miller (1986:251-252) on the Maya ball game and the role of decapitation as earthbound ritual reenactment of mythical games played by the Hero Twins and Underworld Lords. Gillespie (1985) places the ball-game ritual in a similar but broader interpretive context.

${ }^{11}$ Perhaps continuing analyses of the recently discovered Stela 63 of Copán (Stuart et al. 1989), with its two full-figure rabbits at $\mathrm{C} 4$ and $\mathrm{D} 1$ and close association with early members of the dynasty, will help clarify the situation concerning the complex of concepts.

${ }_{12}$ This remark leads one to ask whether 8 Lamat 6 Tzec, the calendar-round date from Str. 8L-74, might be significant in terms of astronomical phenomena involving the moon and Venus, and perhaps the sun. Preliminary examination of computer-simulated sky charts for pertinent Gregorian dates plus ongoing consultation with Anthony Aveni suggest this line of inquiry may repay further pursuit.

${ }^{13}$ Thanks to Christine Carrelli and Marie Selvaggio for suggestions as to the possible symbolic nature of the hemisphere.

${ }^{14}$ One of the Gregorian equivalents for the calendar-round date of Str. 8L-74 falls in A.D. 790, which is within Yax Pac's reign, and may be the dedicatory date of the building. Unfortunately, available archaeological evidence does not link the construction preferentially with that or any of the three potential equivalents (i.e., in A.D. 738, 790, or 842). Royal Maya burials often followed death by only a few days (e.g., Houston and Mathews 1985; Schele 1991), perhaps thus favoring the A.D. 738 position. But Str. 8L-74 need not be linked to burial rites, and other events in the "afterlife cycle" seem to have occurred at longer and more variable intervals (e.g., Coggins 1988c; Schele 1991; see also Carlsen and Prechtel 1991).

is Carrelli (1990) notes that the bones of this burial were in much poorer condition than those in the very nearby Burial XLII-4, perhaps indicating greater antiquity for XLII-3.

${ }^{16}$ The occurrence of deer-antler tines is suggestive here, in light of the symbolic association between deer and jaguars (e.g., Edmonson 1971:122-127; Tedlock 1985:368-369). Recall too the deer humerus found as part of ("sealing"?) Cache XLII-1.

${ }^{17}$ The "open" southeast corner of Group 8L-12 may have originally been filled, at least partially, by standing architecture, although not likely of substantial size. There is clear evidence that this group, as well as $8 \mathrm{~L}-10$, continues to slide gradually downhill, and stone debris south and east of $8 \mathrm{~L}-12$ attests to what has already been lost (Ashmore, comp. 1988, 1989).

Received December 18, 1990; accepted August 22, 1991 